\title{
Cadmium Application in Tomato: Nutritional Imbalance and Oxidative Stress
}

\author{
Roberta Corrêa Nogueirol • Francisco Antonio Monteiro • Priscila Lupino Gratão • \\ Berenice Kussumoto de Alcântara da Silva • Ricardo Antunes Azevedo
}

Received: 25 January 2016 / Accepted: 16 May 2016/Published online: 26 May 2016

(C) Springer International Publishing Switzerland 2016

\begin{abstract}
Over the last few decades, the concentration of cadmium $(\mathrm{Cd})$ in the environment has increased considerably in many countries due to anthropogenic activities. $\mathrm{Cd}$ is one of the most toxic pollutants in the environment and affects many metabolic processes in plants. The main objective of this study was to evaluate the response of the production, nutritional, and enzymatic antioxidant system of two tomato genotypes (Calabash Rouge and CNPH 0082) grown in tropical soils that were treated with doses of $\mathrm{Cd}$. Soil samples were collected from the layer of earth at a depth of 0 $0.2 \mathrm{~m}$ in areas subjected to a minimum of human disturbance. The concentrations of $\mathrm{Cd}$ applied to the soil samples were $0,1,2$, and 4 times $(0,3,6$, and $12 \mathrm{mg} \mathrm{kg}^{-1}$ of $\left.\mathrm{Cd}\right)$ the agricultural intervention value adopted by current environmental legislation in the state of São Paulo, Brazil. Analysis of superoxide dismutase, catalase, glutathione reductase, guaiacol peroxidase, and ascorbate peroxidase activities, formation of stress indicator compound (malondialdehyde-MDA and
\end{abstract}

R. C. Nogueirol $(\bowtie) \cdot$ B. K. de Alcântara da Silva •

R. A. Azevedo

Departamento de Genética, Universidade de São Paulo (ESALQ/ USP), Piracicaba, SP, Brazil 13418-900

e-mail: robertanogueirol@gmail.com

F. A. Monteiro

Departamento de Ciência do Solo, Universidade de São Paulo

(ESALQ/USP), Piracicaba, SP, Brazil 13418-900

P. L. Gratão

Departamento de Biologia Aplicada à Agropecuária UNESP,

Universidade Estadual Paulista, Jaboticabal, SP, Brazil 14884-900 hydrogen peroxide), parameters of production-dry mass of the shoot and root system (here in after "shoots" and "roots"), as well as nutrition, and both the bioavailable and total levels of this metal in the soil were performed. When the bioavailable content and total levels of $\mathrm{Cd}$ in the soil increased as a result of this metal doses applied, the biomass of both shoots and roots decreased in both genotypes (with the exception of the CNPH 0082 grown in clay soil) and displayed lower SPAD (relative chlorophyll index) values when exposed to contaminated environments with $\mathrm{Cd}$ concentrations. Cadmium treatment resulted in nutritional imbalances, mainly in terms of N, P, and Mn metabolism. Plants subjected to an elevated available content of metal in the soil exhibited increases in content of MDA and hydrogen peroxide and increased activity of catalase, ascorbate peroxidase, and guaiacol peroxidase in plant tissues when grown in both clay soil and sandy soil. Cadmium was phytotoxic to the plants causing a nutritional imbalance, especially on the metabolisms of N, P, and Mn. An oxidative stress condition was established in response to the $\mathrm{Cd}$ treatments applied, which led to changes in peroxidase activity.

Keywords Antioxidant enzymes · Extractants · Mineral plant nutrition $\cdot$ Toxic element $\cdot$ Tropical soils

\section{Introduction}

Over the last few decades, the concentration of cadmium (Cd) in the environment has increased considerably in 
many countries as result of human activities (Gallego et al. 2012). Activities such as mining, foundry, application of fertilizers (Feng et al. 2010), and battery and waste disposal are among the main activities that generate environmental contamination caused by this metal (Chou et al. 2011). In terms of overall water quality in the world, surface runoff in agricultural soils infiltrating aquatic systems is one of the most widespread forms of pollution by heavy metals (ICDA 2012).

In the environment, $\mathrm{Cd}$ is found in low concentrations in the soil, the predominant form being $\mathrm{Cd}^{2+}$ (Verbruggen et al. 2009). The low concentration combined with the low diffusion coefficient of metal in the soil solution suggests that the flow of mass is the predominant ion root contact mechanism for uptake of $\mathrm{Cd}$ by plant roots (Lux et al. 2011). Plants are the main entry route into the animal food chain and the accumulation of this metal in certain plant tissues can lead to commercial rejection of food crops and a decrease in productivity, as well as the danger to human health (Benzarti et al. 2010; Gratão et al. 2012; Dourado et al. 2013).

Cadmium is one of the most worrying environmental contaminants and affects several metabolic processes in plants (Dourado et al. 2014). This metal is also known to inhibit seed germination and root growth, induce aberrations in chromosomes and the formation of micronuclei (Fojtová and Kovarík 2000; Pizzaia 2013), and can cause depolarization of the cytoplasmic membrane and acidification, leading to disruption of the cellular homeostasis (Gratão et al. 2005; Gallego et al. 2012).

In most cases, symptoms of toxicity of this element in plants take the form of binding of the metal to sulfhydryl groups of proteins, which creates a metal-protein complex that interferes with the biosynthesis of chlorophyll and can inhibit photosynthetic enzyme activity in the Calvin cycle (Gallego et al. 2012). Furthermore, an excess of $\mathrm{Cd}$ and other toxic metals can stimulate the production of reactive oxygen species (ROSs), which in turn can cause lipid peroxidation, enzyme inactivation, DNA damage, and loss of membrane selectivity (Gratão et al. 2005, 2015; Gallego et al. 2012; Dourado et al. 2015). Cadmium can also influence the absorption of other elements present in the growth medium, especially potentially competing cationic micronutrients such as copper $(\mathrm{Cu})$, iron $(\mathrm{Fe})$, manganese $(\mathrm{Mn})$, and zinc $(\mathrm{Zn})$ (Rodecap et al. 1994).

Oxidative stress caused by the toxic effect of this element causes cell damage that is irreversible and unleashes the process of programmed cell death (Gallego et al. 2012; Su et al. 2014; Iannone et al. 2015). This may reflect the action of ROS on macromolecules, which promotes modification of nucleic acids, including chromosomal breakdown. Cadmium can cause uncontrolled oxidation which may be mitigated by the antioxidant defense system consisting of antioxidant enzymes such as superoxide dismutase, ascorbate peroxidase, catalase, glutathione reductase, glutathione S-transferase, and guaiacol peroxidase, among others (Souza et al. 2013; Liu et al. 2015; Nogueirol et al. 2015).

The objectives of this study were to evaluate the responses of some key antioxidant enzymes and the productive and nutritional changes in two tomato genotypes-Solanum lycopersicum var. esculentum (Calabash Rouge, a commercial genotype exhibiting a tendency to susceptibility to $\mathrm{Cd}$ and tolerance to aluminum (Al)) and S. lycopersicum var. cerasiforme $(\mathrm{CNPH}$ 0082, a wild genotype that exhibits a certain degree of tolerance to toxic elements, except Al) (Piotto 2012; Nogueirol et al. 2015), found in tropical soils.

\section{Materials and Methods}

\subsection{Plant Material and Treatments}

The experiment was conducted in a greenhouse with soil in pots using two genotypes: $S$. lycopersicum var. esculentum (Calabash Rouge) and S. lycopersicumvar. cerasiforme (CNPH 0082). The seeds were treated with $500 \mathrm{~mL} \mathrm{~L}^{-1}$ sodium hypochlorite for $30 \mathrm{~min}$ and then placed on germination trays containing sand as substrate and irrigated with Hoagland and Arnon solution (1950) with an ionic strength of $10 \%$, every 2 days. After 20 days of germination, seedlings were transfered to pots containing soil. The pots were irrigated with deionized water daily.

Soil samples were collected from the layer between 0 and $0.2 \mathrm{~m}$ in areas that had been subjected to minimal human disturbance (forest fragments). Total Cd concentrations in both soils were virtually nil and available $\mathrm{Cd}$ concentrations were zero at the beginning of the experiment. The clay soil contained $670 \mathrm{~g} \mathrm{~kg}^{-1}$ clay, $70 \mathrm{~g} \mathrm{~kg}^{-1}$ silt, and $260 \mathrm{~g} \mathrm{~kg}^{-1}$ sand and a sandy soil contained $130 \mathrm{~g} \mathrm{~kg}^{-1}$ clay, $30 \mathrm{~g} \mathrm{~kg}^{-1}$ silt, and $840 \mathrm{~g} \mathrm{~kg}^{-1}$ sand.

The pots containing clay soil were given a corrective (applied in the form of $\mathrm{CaO}$ ) equivalent to $2240 \mathrm{mg}$ of 
$\mathrm{CaO}$ per kilogram of soil and pots containing only sandy soil were given the equivalent of $1120 \mathrm{mg}$ of $\mathrm{CaO}$ per kilogram of soil in order to precipitate all the toxic $\mathrm{Al}$ in the soil and to ensure soil acidity within the appropriate range for $\mathrm{Cd}$ to be applied. The corrective doses were established by neutralization curves previously calculated for each soil.

Cadmium source was $\mathrm{CdCl}_{2}$ and the rates of $\mathrm{Cd}$ were supplied to the plants as solutions to have this metal homogenized in the soil. The $\mathrm{Cd}$ concentrations applied to the soil were $0,1,2$, and 4 times $(0,3,6$, and $\left.12 \mathrm{mg} \mathrm{kg}^{-1} \mathrm{Cd}\right)$ the agricultural intervention level ( $3 \mathrm{mg} \mathrm{kg}^{-1}$ soil) adopted by current environmental legislation in the state of São Paulo, Brazil (CONAMA 2009).

\subsection{Available and Total Contents of Cd in the Soil}

Available Cd contents in the soil were extracted by Mehlich-III (Mehlich 1984), and the total metal concentration was obtained by the EPA method 3052, employing microwave digestion using $\mathrm{HF}+\mathrm{HNO}_{3}+$ ultrapure water (EPA 1996). Metal levels in the extracts were determined by ICP-OES.

\subsection{Dry Mass Yield and Mineral Elements in Plant} Tissues

The plants were harvested 34 days after transplanting the seedlings to the soil. The plant material used in the evaluation of productive and nutritional aspects was separated into shoots and roots and dried in a forced circulation oven at $65^{\circ} \mathrm{C}$ for $72 \mathrm{~h}$, and subsequently ground in a Wiley mill. The samples were subjected to nitric-perchloric digestion according to Malavolta et al. (1997) and Cd concentrations were determined by ICPOES. Nitrogen concentration in the samples was determined by sulfuric acid digestion, followed by distillation and titration; phosphorus (P) by colorimetry; potassium (K) by flame photometry; sulfur (S) turbidimetrically; and copper $(\mathrm{Cu})$, iron $(\mathrm{Fe})$, manganese $(\mathrm{Mn})$, and zinc (Zn) by atomic absorption spectrophotometry.

\subsection{SPAD Value}

The indirect determination of the concentration of chlorophyll in the SPAD value (relative chlorophyll index) was carried out with a SPAD-502 Chlorophyll Meter after the onset of signs of Cd toxicity in the plants (5 days after the metal soil application). Values used for statistical analysis were derived from an average of ten readings taken for each pot.

\subsection{Lipid Peroxidation and $\mathrm{H}_{2} \mathrm{O}_{2}$ Content}

Lipid peroxidation was assessed by the 2-thiobarbituric acid (TBA) test. The content of the reactive substances (TBARS) was quantified as the final product of the process of lipid peroxidation, with readings at 535 and $600 \mathrm{~nm}$ (Gratão et al. 2012). Malondialdehyde (MDA) content was calculated from the specific equation for the reaction (Mihara et al. 1980). $\mathrm{H}_{2} \mathrm{O}_{2}$ content was determined according to Gay et al. (1999). $\mathrm{H}_{2} \mathrm{O}_{2}$ present in the sample donates electrons to the Fe which binds to the xylenol during the incubation period $(30 \mathrm{~min})$. The readings of both the standard curve and the samples were read by a spectrophotometer at $560 \mathrm{~nm}$.

2.6 Extraction and Quantification of Proteins in Leaves and Roots

The plant material used for enzymatic analysis was collected, immediately frozen in liquid nitrogen, and stored in a freezer at $-80{ }^{\circ} \mathrm{C}$. Proteins were extracted from $1 \mathrm{~g}$ macerated tissue in a mortar with liquid nitrogen. Samples were homogenized in $100 \mathrm{mM}$ potassium phosphate buffer, $\mathrm{pH} 7.5$, containing $1 \mathrm{mM}$ ethylene diaminetetraacetic acid (EDTA), $3 \mathrm{mM}$ dithiothreitol (DTT), and $4 \mathrm{~g} \mathrm{~L}^{-1}$ polyvinylpolypyrrolidone (PVPP) according to Azevedo et al. (1998). The homogenate was centrifuged at $10,000 \times g$ for $30 \mathrm{~min}$ at $4{ }^{\circ} \mathrm{C}$ and the supernatant was aliquoted and stored in a freezer at $-80{ }^{\circ} \mathrm{C}$ until analysis. The concentration of total proteins was determined by the Bradford method (1976) using the "Bovine Serum Albumin" (BSA) as standard. The result was expressed in miligram protein/Mililiter of protein extract.

\subsection{Antioxidant Enzymes}

\subsubsection{Superoxide Dismutase}

SOD activity staining was carried out as described by Rendón et al. (2013). After non-denaturing polyacrylamide gel (PAGE) separation, the gel was rinsed in deionized water and incubated in the dark in $50 \mathrm{mM}$ potassium phosphate buffer ( $\mathrm{pH} 7.8$ ) containing $1 \mathrm{mM}$ EDTA, $0.1 \mathrm{mM}$ nitroblue tetrazolium, $0.05 \mathrm{mM}$ riboflavin, and $0.3 \mathrm{~g} N, N, N, N^{\prime}$ tetramethylethylenediamine. 
The gels were then rinsed with deionized water and illuminated in water until the achromatic bands of SOD activity were visible on a purple-stained gel. Bovine SOD was used as a standard.

\subsubsection{Catalase}

The activity of catalase (CAT) was determined by a reaction containing $1 \mathrm{~mL}$ of $100 \mathrm{mM}$ potassium phosphate buffer, pH 7.5, and $2.5 \mu \mathrm{L} \mathrm{H}_{2} \mathrm{O}_{2} 30 \%$, to which $15 \mu \mathrm{L}$ of protein extract was added. CAT activity was determined by the decomposition of $\mathrm{H}_{2} \mathrm{O}_{2}$ for $1 \mathrm{~min}$ in a spectrophotometer $(240 \mathrm{~nm})$ at $25^{\circ} \mathrm{C}$ (Monteiro et al. 2011).

\subsubsection{Ascorbate Peroxidase}

The activity of ascorbate peroxidase (APX) was determined by the spectrophotometric method, with readings taken at $290 \mathrm{~nm}$. The reaction mixture consisted of a solution containing $650 \mu \mathrm{L}$ of $80 \mathrm{mM}$ potassium phosphate buffer, $\mathrm{pH} 7.0,100 \mu \mathrm{L}$ ascorbate $5 \mathrm{mM}, 100 \mu \mathrm{L}$ $1 \mathrm{mM}$ EDTA, $100 \mu \mathrm{L} \mathrm{H}_{2} \mathrm{O}_{2} 1 \mathrm{mM}$, and $50 \mu \mathrm{L}$ extract, kept in a water bath at $30{ }^{\circ} \mathrm{C} . \mathrm{H}_{2} \mathrm{O}_{2}$ was added at the time the readings were taken after a period of $1 \mathrm{~min}$ in quartz cuvettes (Cakmak and Horst 1991). The activity of APX, expressed as nanomole per minute per miligram protein in the presence of ascorbate, was calculated using the extinction coefficient of $2.8 \mathrm{mM}^{-1} \mathrm{~cm}^{-1}$ ascorbate (Monteiro et al. 2011).

\subsubsection{Glutathione Reductase}

The activity of glutathione reductase (GR) was measured using a spectrophotometer $(412 \mathrm{~nm})$ at $30{ }^{\circ} \mathrm{C}$. Fifteen microliters of extract was added to a reaction solution consisting of $3 \mathrm{~mL}$ of $100 \mathrm{mM}$ potassium phosphate buffer, $\mathrm{pH} 7.5,1.5 \mathrm{~mL}$ 5,5'-dithio-bis (2nitrobenzoic acid) (DTNB), $1 \mathrm{mM}$ oxidized glutathione, and $0.1 \mathrm{mM}$ NADPH. GR activity was estimated by reduction of oxidized glutathione (Carvalho et al. 2013) and was expressed in micromole per minute per miligram protein.

\subsubsection{Guaiacol Peroxidase}

The activity of guaiacol peroxidase (GPOX) was determined according to Matsuno and Uritani (1972). The reaction medium consisted of phosphate-citrate buffer
(pH 5.0), guaiacol $5 \mathrm{~mL} \mathrm{~L}^{-1}$, and protein extract $(50 \mu \mathrm{L})$, kept at $30^{\circ} \mathrm{C}$ for $15 \mathrm{~min}$. An ice bath and the addition of $20 \mathrm{~g} \mathrm{~L}^{-1}$ of sodium metabisulfite were used to stop the reaction and readings were taken at $450 \mathrm{~nm}$. One enzyme activity unit (U) of GPOX corresponds to an increase of 0.001 in absorbance per minute per miligram protein.

\subsection{Statistical Analysis}

The experiment was set in complete randomized block design, with three replications to evaluate plant production and mineral nutrition, and other three replications for metabolic parameters determinations. Each experimental unit (pot) had three plants. Results were expressed in terms of means and standard deviations of the mean $( \pm \mathrm{SD})$ in three independent repetitions focused on dry mass production and nutrients and $\mathrm{Cd}$ concentrations in both shoots and roots, $\mathrm{Cd}$ concentrations available and total content in the soil, and antioxidant enzymes activity. The results were analyzed by means of an SAS program (2002) and the Tukey test ( $5 \%$ level of significance) was applied to the variance analysis and comparisons of means.

\section{Results}

\subsection{Available and Total Contents of $\mathrm{Cd}$ in the Soil}

Cadmium concentrations available determined at the end of the experiment, extracted by Mehlich-III, increased with the concentration of metal applied to both soils (Fig. 1a, b). This explains why the contents extracted by Mehlich-III were smaller than the initial amounts added, which were readily available, since they had been administered in the form of a solution to plants during the pre-flowering period to allow for greater $\mathrm{Cd}$ absorption. The total contents extracted by the EPA 3052 method, a closed digestion system, were very close to the amounts administered and increased according to the $\mathrm{Cd}$ concentrations applied in both soils (Fig. 1c, d).

\subsection{Dry Mass Production}

The growth rate of the plants declined as the concentration of $\mathrm{Cd}$ applied to the soil increased from 6 to $12 \mathrm{mg} \mathrm{kg}^{-1}$. Calabash Rouge exhibited lower 
CLAY SOIL

SANDY SOIL

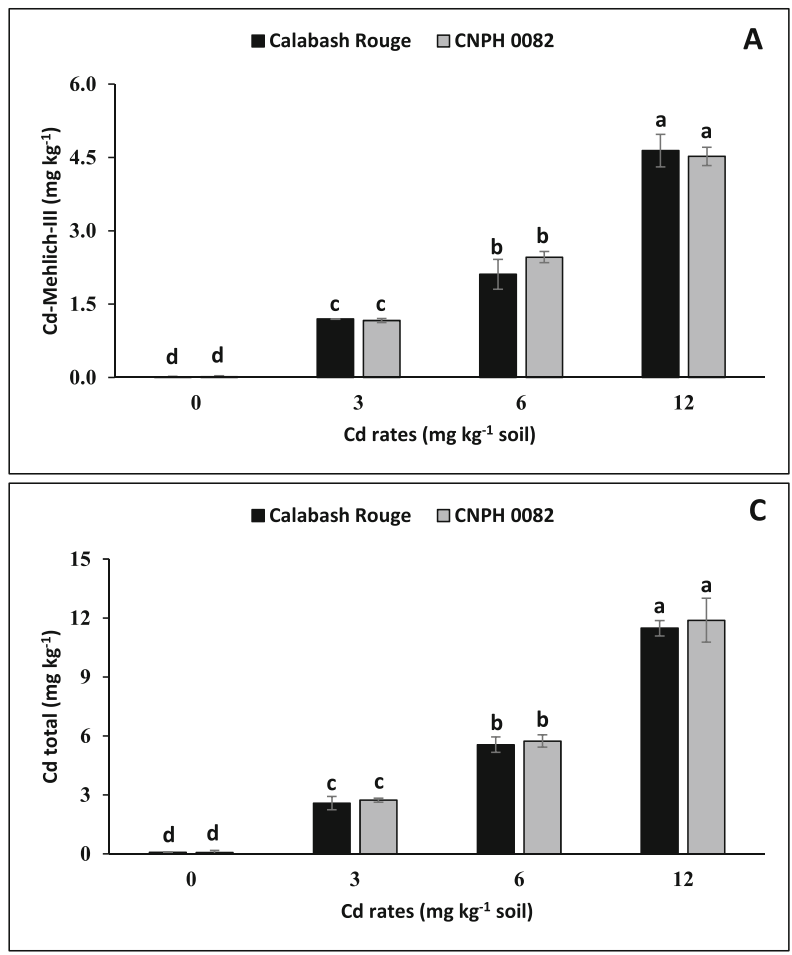

Fig. 1 Cd-Mehlich-III $(\mathbf{a}, \mathbf{b})$ and total $\mathrm{Cd}(\mathbf{c}, \mathbf{d})$ in soil for Calabash Rouge and CNPH 0082 genotypes, as related to $\mathrm{Cd}$ rates. Values are the means of three replications $\pm \mathrm{SD}$. Different
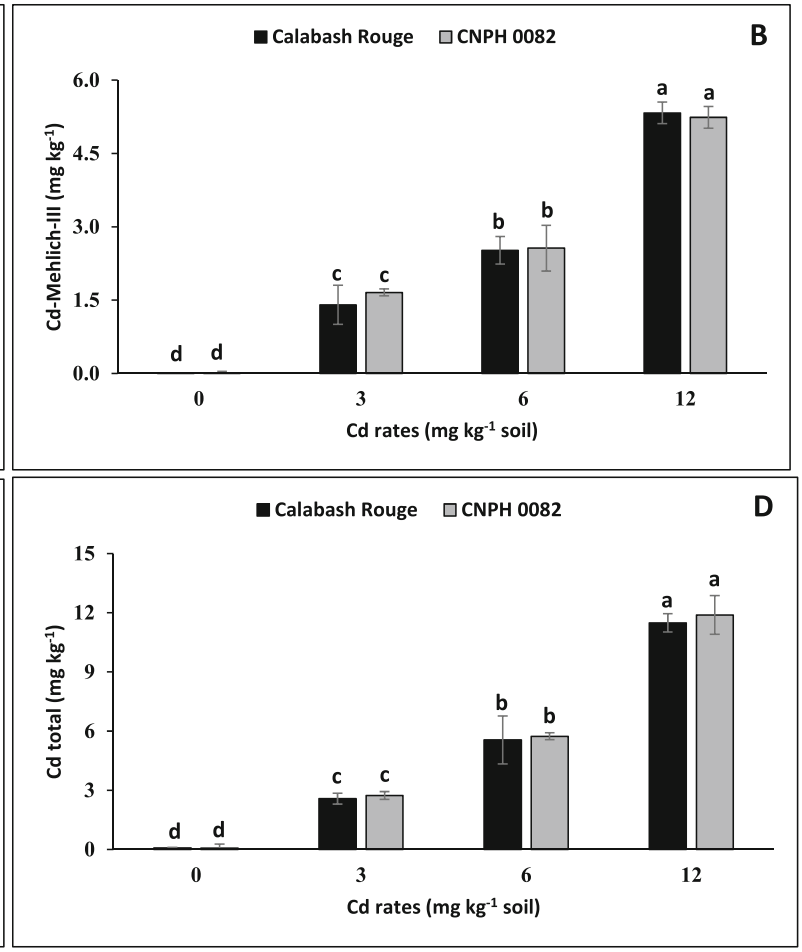

letters within each soil and each genotype indicate significant differences among means (Tukey, $5 \%$ )

production of shoot and root dry mass only when treated with the higher concentration of $\mathrm{Cd}\left(12 \mathrm{mg} \mathrm{kg}^{-1}\right)$ in the clay soil, while CNPH 0082 exhibited lower shoot dry mass production when treated with $\mathrm{Cd}$ concentrations of either 6 or $12 \mathrm{mg} \mathrm{kg}^{-1}$ (Fig. 2a), whereas no change in root dry mass that could be attributed to the presence of metal in the culture medium was observed (Fig. 2c). In sandy soil, both genotypes exhibited lower shoot dry mass production only at the highest $\mathrm{Cd}$ concentration use remaining unaffected by the other concentrations applied to the soil (Fig. 2b). Calabash Rouge exhibited the highest root dry mass production at $3 \mathrm{mg} \mathrm{kg}^{-1} \mathrm{Cd}$ concentration, while CNHP 0082 exhibited lower root growth than the control at all concentrations of $\mathrm{Cd}$ used (3, 6, or $\left.12 \mathrm{mg} \mathrm{kg}^{-1}\right)$ (Fig. 2d).

\subsection{SPAD Value}

In the clay soil, the SPAD values for both genotypes decreased in response to the $\mathrm{Cd}$ treatments applied to the soil (Fig. 3a). The Calabash Rouge cultivar under cultivation in sandy soil exhibited reduced SPAD values that

could be attributed to the concentration of metal applied, while for CNPH 0082 the increases in the concentrations used had no effect on SPAD value, though a reduction was evident when plants treated with any concentration of $\mathrm{Cd}$ were compared to plants that were not subjected to metal treatment (Fig. 3b).

\subsection{Cd Concentration in Plant Tissues}

Cd concentrations in the shoots and roots of both cultivars increased with the application of metal concentration in both soil types (Fig. 4). The Cd concentration was always higher in Calabash Rouge than in the $\mathrm{CNPH}$ 0082, especially when grown in clay soil. Calabash Rouge absorbed and transported more $\mathrm{Cd}$ to the shoots than CNPH 0082, especially when grown in a soil with clay texture (Fig. 4a, c).

\subsection{Concentration of Nutrients in Plant Tissues}

Both genotypes exhibited lower $\mathrm{N}$ concentration than the control in the shoots when the concentrations of $\mathrm{Cd}$ 


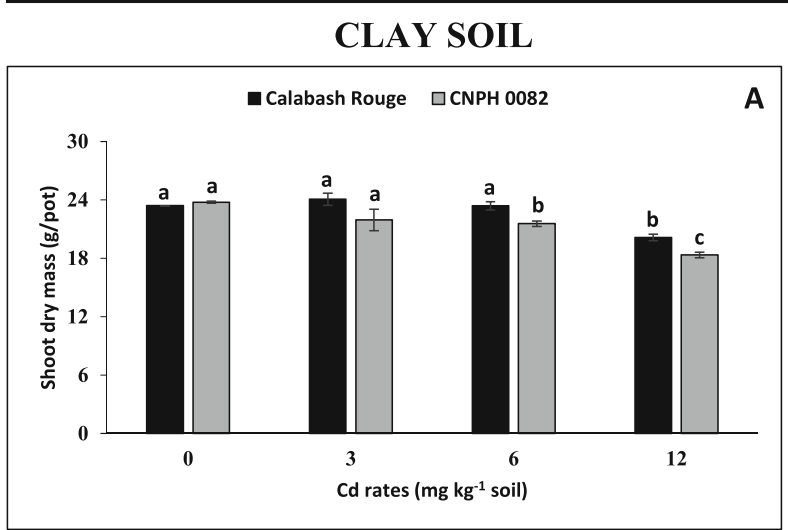

A

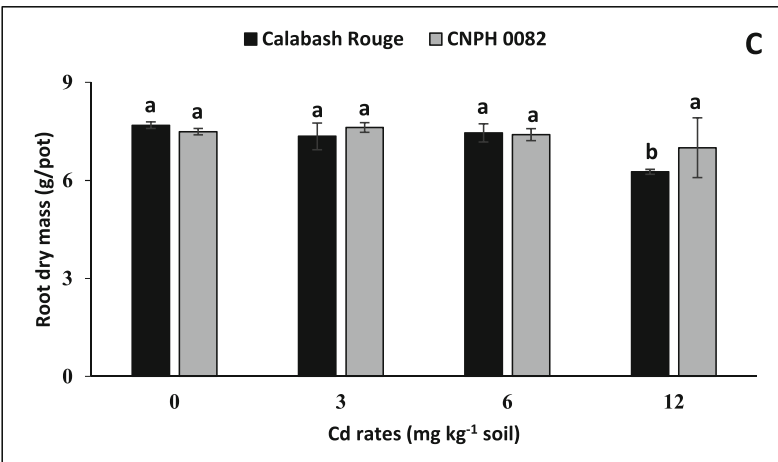

Fig. 2 Shoots $(\mathbf{a}, \mathbf{b})$ and roots $(\mathbf{c}, \mathbf{d})$ dry mass of plants grown over a 54-day period since germination, as related to Cd rates in two soil types. Values are the means of three replications \pm SD. Different

were applied to both soils (Fig. 5a, b). The N concentrations in plants grown in clay soil were higher than in those grown in sandy soil. Calabash Rouge exhibited a more pronounced decrease in $\mathrm{N}$ concentration in the shoots when compared to CNPH 0082. The N concentration in the roots of Calabash Rouge grown in clay soil

\section{CLAY SOIL}

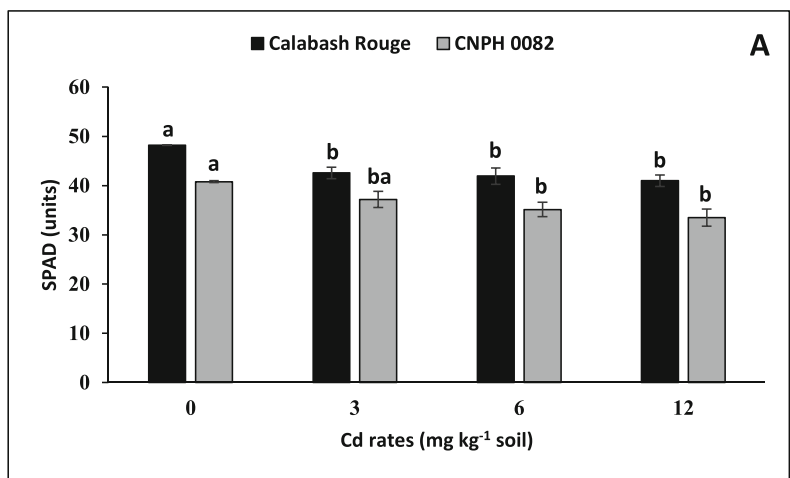

Fig. 3 SPAD units of plants grown over a 54-day period since germination, as related to cadmium rates in two soil types. Values are the means of three replications \pm SD. Different letters within
SANDY SOIL
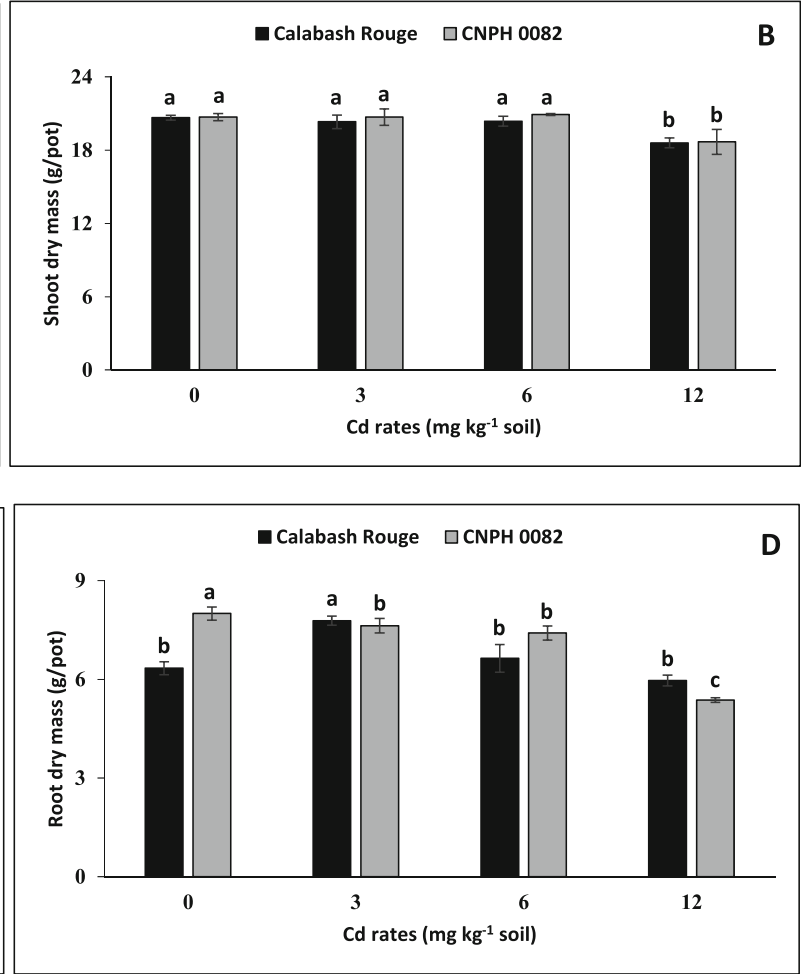

letters within each soil and each genotype indicate significant differences among means (Tukey, $5 \%$ )

changed in response to the $\mathrm{Cd}$ concentration applied to the soil, while the $\mathrm{N}$ concentration in $\mathrm{CNPH} 0082$ roots remained constant (Fig. 5c). There was an increase in $\mathrm{N}$ concentration in the roots of both genotypes grown in sandy soil in conditions of great availability of $\mathrm{Cd}$ (Fig. 5d).

\section{SANDY SOIL}

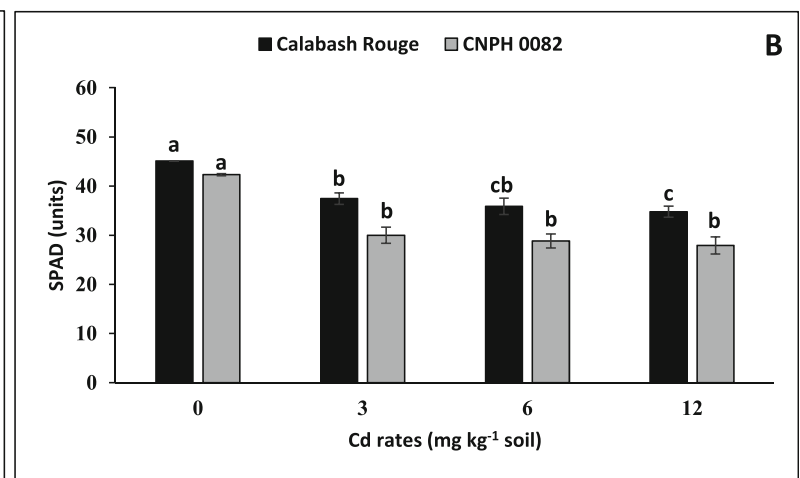

each soil and each genotype indicate significant differences among means (Tukey, $5 \%$ ) 
CLAY SOIL

SANDY SOIL

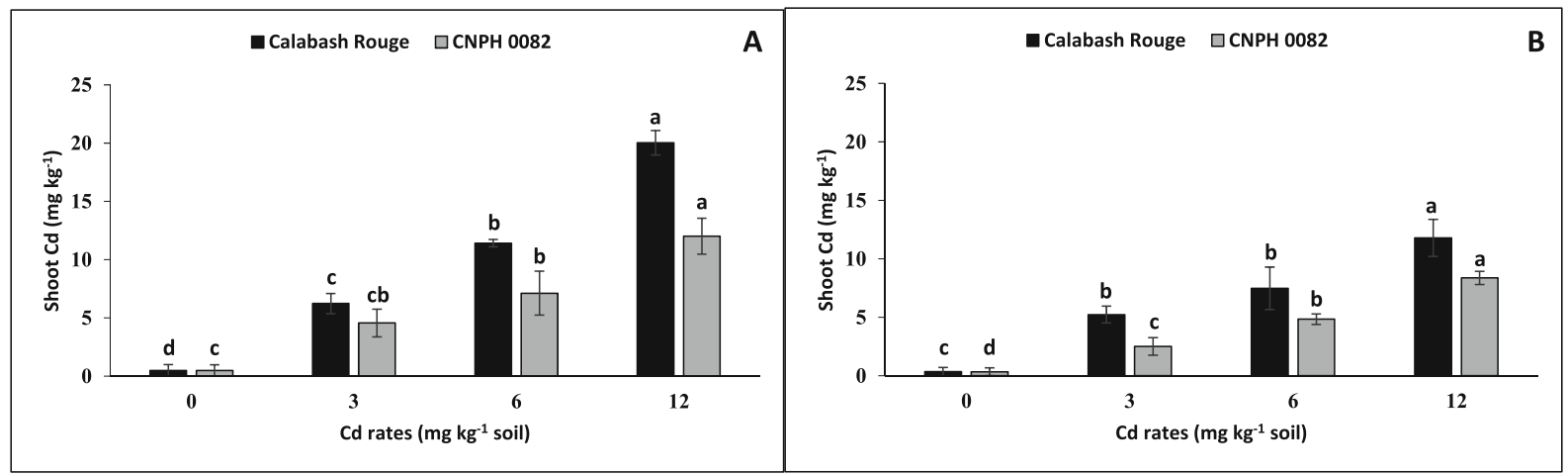

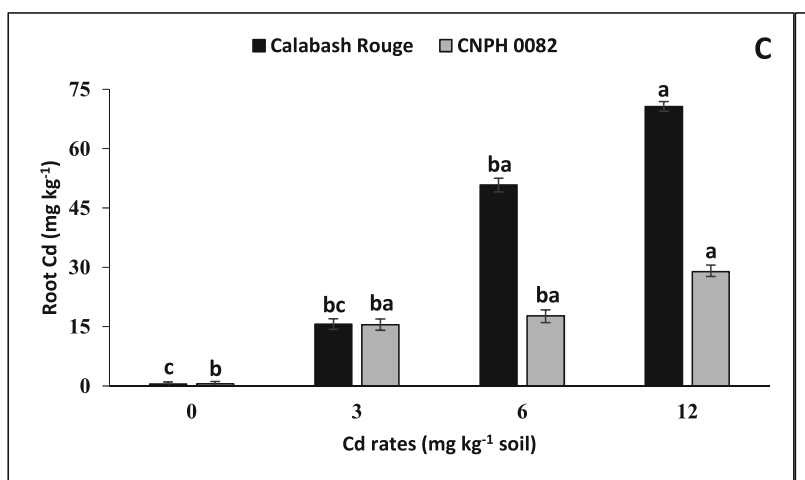

Fig. 4 Cadmium concentrations in shoot $(\mathbf{a}, \mathbf{b})$ and $\operatorname{root}(\mathbf{c}, \mathbf{d})$ of Calabash Rouge and CNPH 0082 genotypes, as related to $\mathrm{Cd}$ rates in two soil types. Values are the means of three replications \pm SD.

Phosphorus concentrations were unchanged in vegetal tissues of the shoots (Fig. 6a) and roots (Fig. 6c) of the two genotypes when exposed to $\mathrm{Cd}$ in clay soil. When grown in sandy soil, Calabash Rouge exhibited an increase in $\mathrm{P}$ concentration in the presence of $\mathrm{Cd}$, while no change was observed in CNPH 0082 (Fig. 6b). In the root tissue of plants grown in sandy soil, $\mathrm{P}$ concentrations decreased continuously as the applied metal concentrations increased (Fig. 6d).

In plants grown in clay soil, lower Mn concentration was observed in shoots of Calabash Rouge with $\mathrm{Cd}$ concentration of 3 and $6 \mathrm{mg} \mathrm{kg}^{-1}$, while CNPH 0082 exhibited lower concentrations of this micronutrient in response to the $\mathrm{Cd}$ concentrations applied (Fig. 7a). For root tissue, Calabash Rouge exhibited a higher $\mathrm{Mn}$ concentration at $3 \mathrm{mg} \mathrm{kg}^{-1} \mathrm{Cd}$ in the soil than for the other concentrations applied, while CNPH 0082 differed from the control only at $3 \mathrm{mg} \mathrm{kg}^{-1} \mathrm{Cd}$ in the soil (Fig. 7c). When grown in sandy soil, only Calabash Rouge exhibited a reduction in the concentration of this micronutrient and to the same extent in both shoots and roots, in response to the $\mathrm{Cd}$ concentrations used (Fig. 7c, d).

No changes were observed for any of the genotypes and in both soils used in the concentrations of $\mathrm{K}, \mathrm{Ca}$, $\mathrm{Mg}, \mathrm{S}, \mathrm{Cu}, \mathrm{Fe}$, and $\mathrm{Zn}$ (shoots and roots) in response to the $\mathrm{Cd}$ concentrations (results not shown).

\subsection{Lipid Peroxidation and $\mathrm{H}_{2} \mathrm{O}_{2}$ Content}

Lipid peroxidation measured as MDA content in the shoots was higher at 6 to $12 \mathrm{mg} \mathrm{kg}^{-1}$ for Calabash Rouge, while for CNPH 0082 lipid peroxidation was higher at $12 \mathrm{mg} \mathrm{kg}^{-1}$ when compared to the other concentrations applied to both types of soil (Fig. 8a, b). In the roots of both genotypes, lipid peroxidation was higher in the plants subjected to the two highest concentrations of $\mathrm{Cd}$ than for the other concentrations in both soils (Fig. 8c, d). The concentration of $\mathrm{H}_{2} \mathrm{O}_{2}$ in the shoots increased in both genotypes as a result of the $\mathrm{Cd}$ concentrations applied to both soils (Fig. 9a, b). Calabash Rouge in both soils and $\mathrm{CNPH}$ 

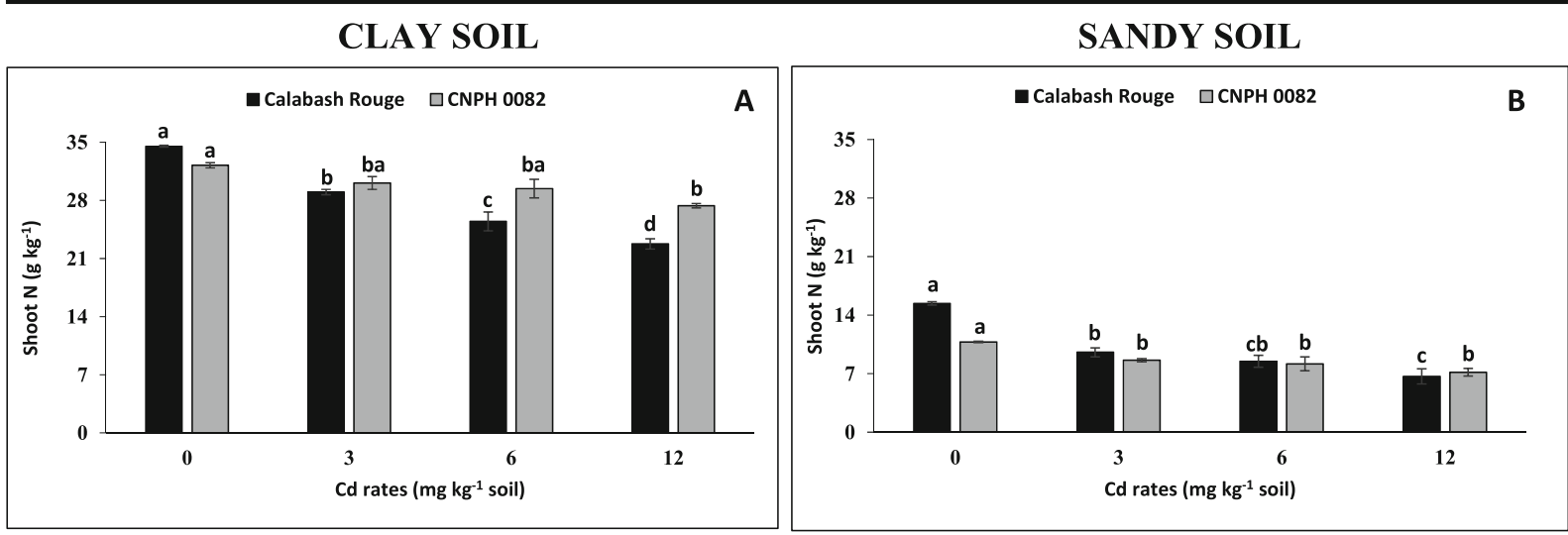

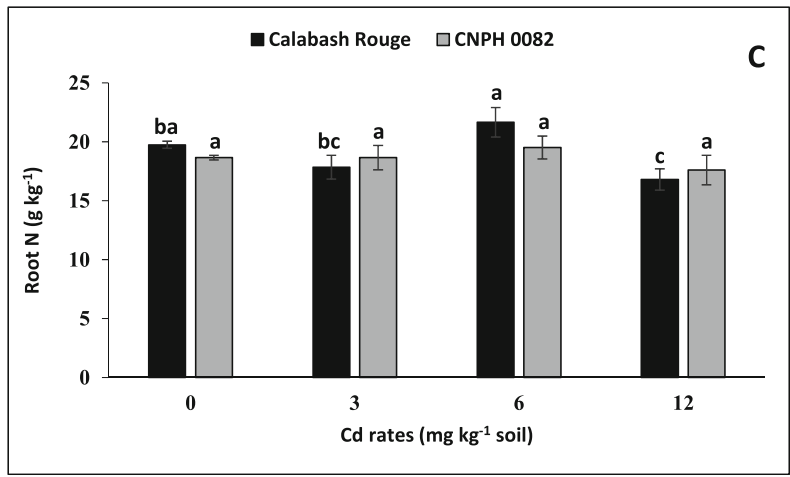

Fig. 5 Nitrogen concentrations in shoot $(\mathbf{a}, \mathbf{b})$ and root $(\mathbf{c}, \mathbf{d})$ of Calabash Rouge and CNPH 0082 genotypes, as related to Cd rates in two soil types. Values are the means of three replications \pm SD.

0082 in the sandy soil only exhibited an increased production of $\mathrm{H}_{2} \mathrm{O}_{2}$ in the roots in line with the increases in metal availability for plant absorption, while for the CNPH 0082 in clay soil the two higher Cd concentrations resulted in greater $\mathrm{H}_{2} \mathrm{O}_{2}$ content (Fig. 9c, d).

\subsection{Antioxidant Enzymes}

\subsubsection{Superoxide Dismutase (SOD)}

The determination of SOD activity in samples extracted from the plants was based on the separation of isoenzymes by non-denaturing PAGE (Fig. 10). Three SOD isoenzymes were detected in the shoots and roots (bands 1,2, and 3). Although a densitometric analysis was not carried out, it was possible to observe a continuous increase in band 3 intensity in line with increases in $\mathrm{Cd}$ concentrations in the leaves of $\mathrm{CNPH}$ in clay soil (Fig. 10a). In the roots, an increase in band 3 intensity was observed for Calabash Rouge grown in clay soil as Cd availability increased (Fig. 10c).

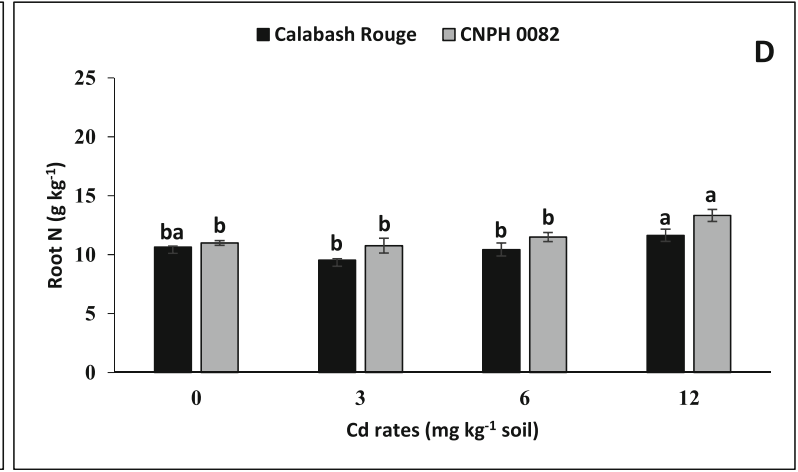

Different letters within each soil and each genotype indicate significant differences among means (Tukey, $5 \%$ )

\subsubsection{Catalase (CAT)}

CAT activity increased in the shoots of both genotypes in response to the $\mathrm{Cd}$ concentrations applied to the soil (Fig. 11a, b). When grown in clay soil, Calabash Rouge exhibited an increase in CAT activity in the roots in response to the increase in $\mathrm{Cd}$ availability, while CNPH 0082 was different only from the control and when the $\mathrm{Cd}$ concentration was $12 \mathrm{mg} \mathrm{kg}^{-1}$ (Fig. 11c). In sandy soil, the highest activity of this enzyme was observed in the roots at the two highest metal concentrations used (Fig. 11d).

\subsubsection{Ascorbate peroxidase (APX)}

In the clay soil, APX activity in the shoots of Calabash Rouge was higher at the highest concentration of $\mathrm{Cd}$ in the soil when compared to the other concentrations applied, while in CNPH 0082 APX activity showed no significant difference between $\mathrm{Cd}$ concentrations (Fig. 12a). APX activity in the shoots in Calabash 

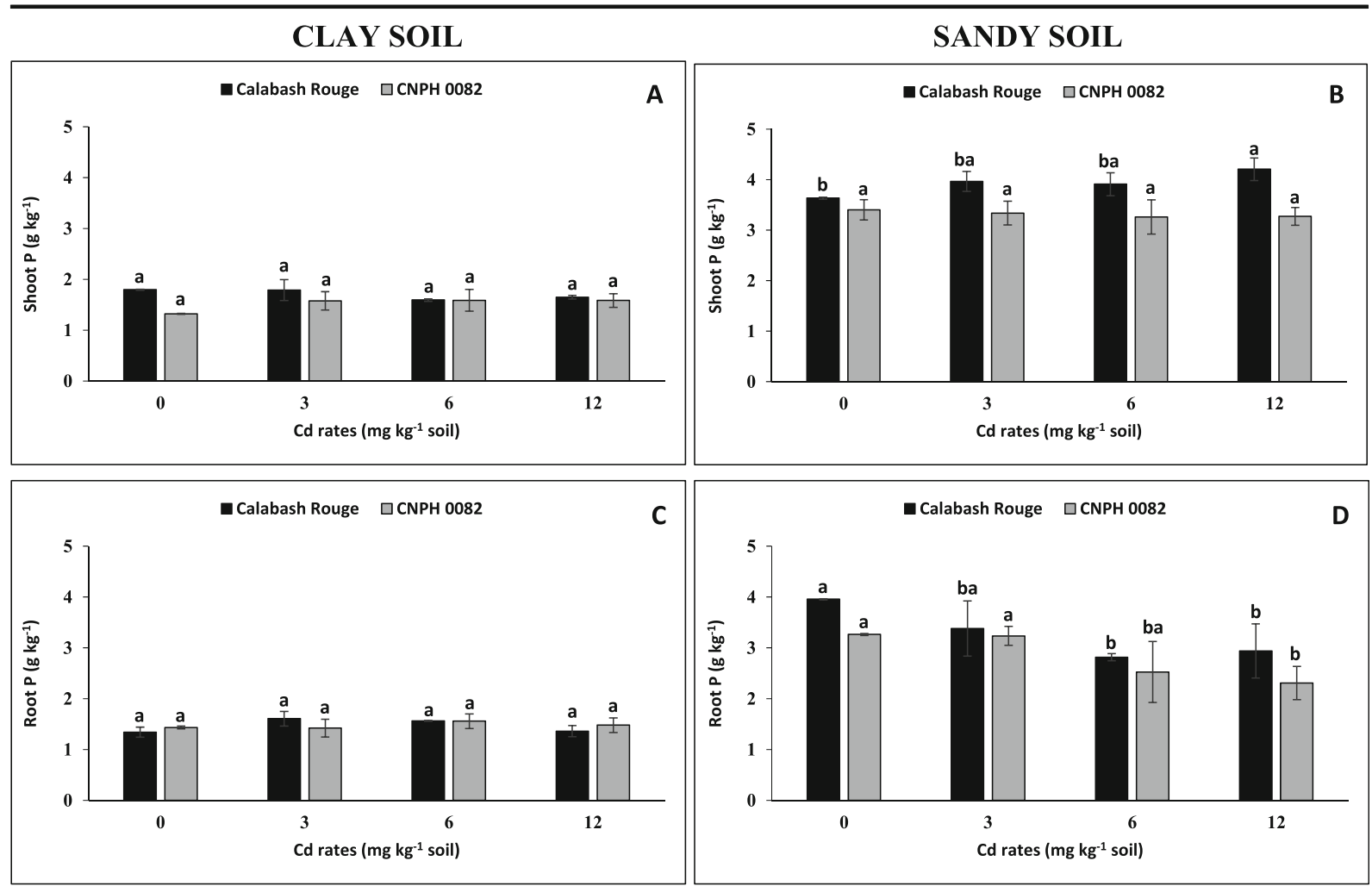

Fig. 6 Phosphorus concentrations in $\operatorname{shoot}(\mathbf{a}, \mathbf{b})$ and $\operatorname{root}(\mathbf{c}, \mathbf{d})$ of Calabash Rouge and CNPH 0082 genotypes, as related to Cd rates in two soil types. Values are the means of three replications \pm SD.

Rouge remained unchanged in response to all levels of Cd concentration, while CNPH 0082 exhibited increased activity for the two highest concentrations of $\mathrm{Cd}$ above those of the control and the concentration of $3 \mathrm{mg} \mathrm{kg}{ }^{-1}$ when plants were grown in sandy soil (Fig. 12b). APX activity in the roots of Calabash Rouge grown in clay soil was higher at the two highest concentrations of $\mathrm{Cd}$ than at the other concentrations, while for CNPH 0082 a difference was only observed at the highest concentration used (Fig. 12c). When grown in sandy soil, the root tissues of both genotypes exhibited higher APX activity when exposed to higher availability of the metal (Fig. 12d).

\subsubsection{Glutathione Reductase (GR)}

In clay soil and in both genotypes, GR activity in the shoots and roots was unaffected by any concentration of Cd (Fig. 13a, c). GR activity was higher in the shoots of CNPH 0082 when subjected to $12 \mathrm{mg} \mathrm{kg}^{-1} \mathrm{Cd}$ when compared with to the enzyme activity at $3 \mathrm{mg} \mathrm{kg}^{-1} \mathrm{Cd}$ and the control (Fig. 13b). GR activity in the roots of the

Different letters within each soil and each genotype indicate significant differences among means (Tukey, $5 \%$ )

both genotypes was not influenced by any treatments when grown in sandy soil (Fig. 13d).

\subsubsection{Guaiacol Peroxidase (GPOX)}

GPOX activity in the shoots of CNPH 0082 was not altered by $\mathrm{Cd}$ in either clay or sandy soil (Fig. 14a, b). In Calabash Rouge, only the highest Cd concentration led to a higher GPOX activity in shoots of the plants grown in sandy soil (Fig. 14b) and roots of the plants grown in clay soil (Fig. 14c). CNPH 0082 exhibited changes in GPOX activity at the two highest concentrations of $\mathrm{Cd}$ in roots of plants grown in sandy soil (Fig. 14d).

\section{Discussion}

The bioavailable $\mathrm{Cd}$ concentrations (Fig. 1a, b) were lower than the total content (Fig. 1c, d) owing to the soil-metal interaction that occurred between the time when $\mathrm{Cd}$ was applied and the time of harvesting of the soil sample. This decline can be related to the application 
CLAY SOIL
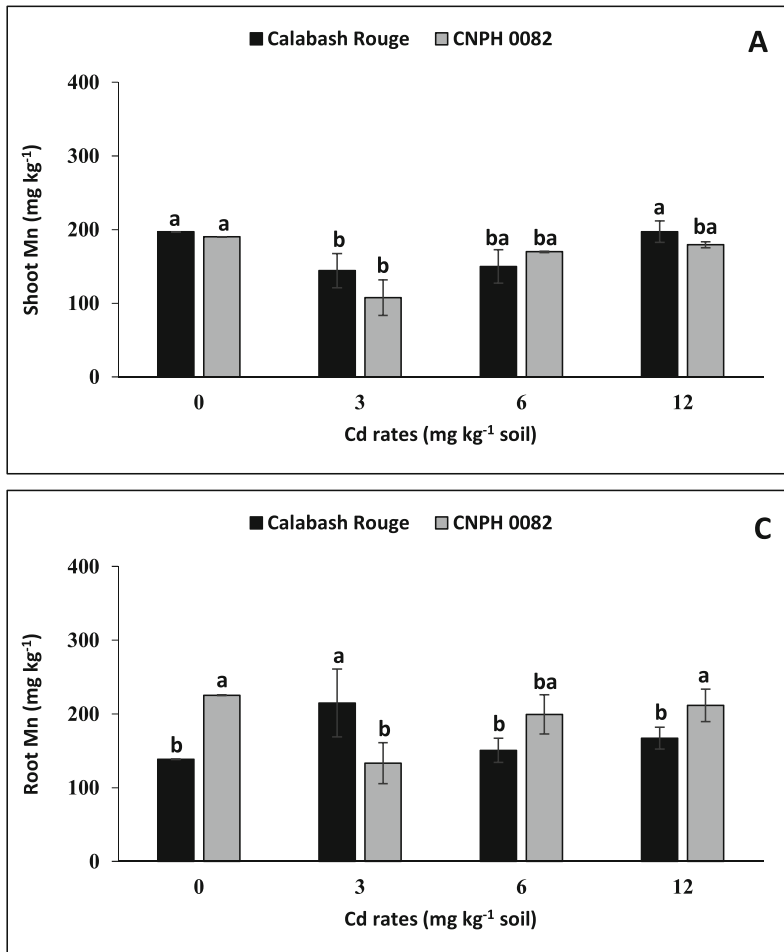

Fig. 7 Manganese concentrations in shoot $(\mathbf{a}, \mathbf{b})$ and root $(\mathbf{c}, \mathbf{d})$ of Calabash Rouge and CNPH 0082 genotypes, as related to Cd rates in two soil types. Values are the means of three replications \pm SD.

of $\mathrm{Cd}$ via solution, which can avoid any part of the $\mathrm{Cd}$ amount being retained by soil particles and unavailable to plants. Contaminants remain in the environment for a long time, and at times tend to display slow build-up because they do not degrade and are little metabolized by living organisms. $\mathrm{Cd}$ is a toxic metal which can be easily taken up by plants disrupting the control of the cell redox, being one of the major stresses that limit agricultural production (Clemens 2006). Thus, heavy metals which accumulate can remain in the environment for a long time and eventually accumulating to levels that could harm humans (Gratão et al. 2005; Azevedo et al. 2012).

Both tomato genotypes chosen for this study exhibited lower growth of both shoots (Fig. 2a, b) and roots (Fig. 2c, d) due to the increase in metal concentration in the soil. $\mathrm{Cd}$ is an element easily absorbed by plant roots. Subsequent uptake by plants occurs when root cells die, affecting root development and plant growth. Dry mass production for both genotypes was similar; however, the amount of $\mathrm{Cd}$ absorbed by the roots and transported to the shoots in the Calabash Rouge genotype was greater than for the CNPH 0082 genotype, indicating a higher

\section{SANDY SOIL}
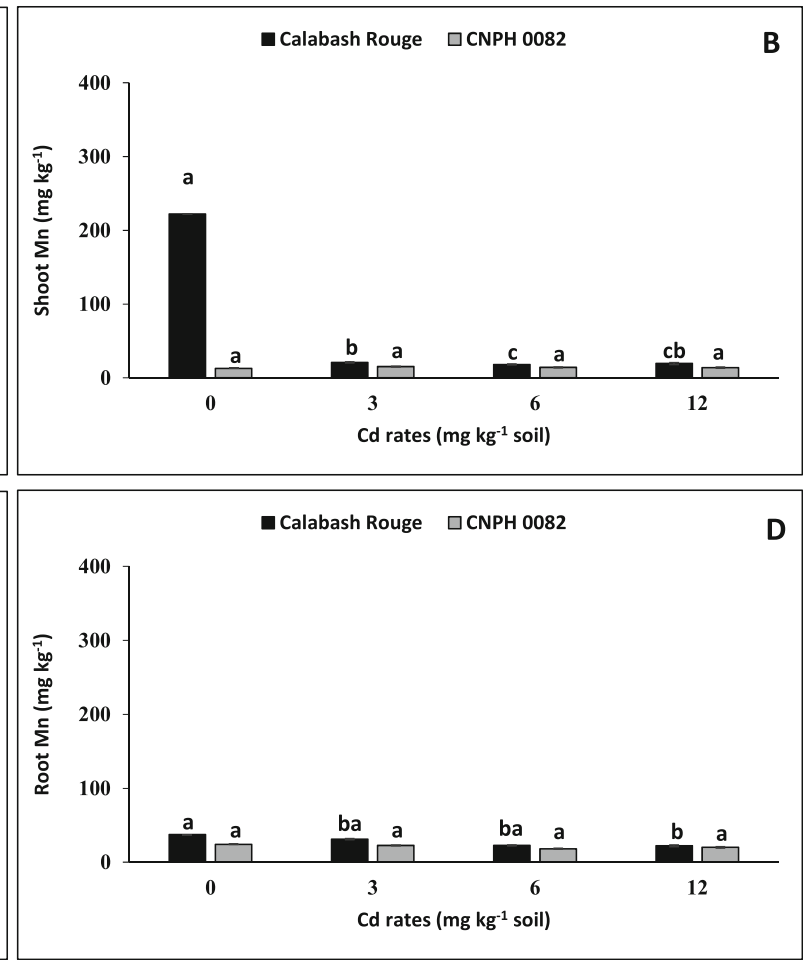

Different letters within each soil and each genotype indicate significant differences among means (Tukey, $5 \%$ )

level of tolerance of this genotype to this metal. Such a result may also point out to a potential mechanisms of plant tolerance to $\mathrm{Cd}$. Moreover, the higher amount absorbed coupled with the rapid transport of a toxic element from the roots to the shoots of a plant are desirable characteristics in species used for phytoremediation of areas contaminated by heavy metals, since the majority of these metals tend to accumulate in the root tissue of plants. It is also to bear in mind that plant organ differ in their sensitivity to $\mathrm{Cd}$ exposure due to the allocation of biomass when exposed to the stress imposed by Cd (Djebali et al. 2010).

The presence of $\mathrm{Cd}$ in plant tissues caused nutritional and productive changes in both tomato genotypes in both types of soil, resulting in lower SPAD values (Fig. 3a, b). Plants grown in soil contaminated with $\mathrm{Cd}$ exhibited chlorosis in the leaves, which may have been caused by the change in the balance of water and stomatal conductance in addition to the damaging effect of the metal to the photosynthetic apparatus, which causes decreases in the chlorophyll and carotenoid contents (Sanità di Toppi and Gabrielli 1999), displaying 

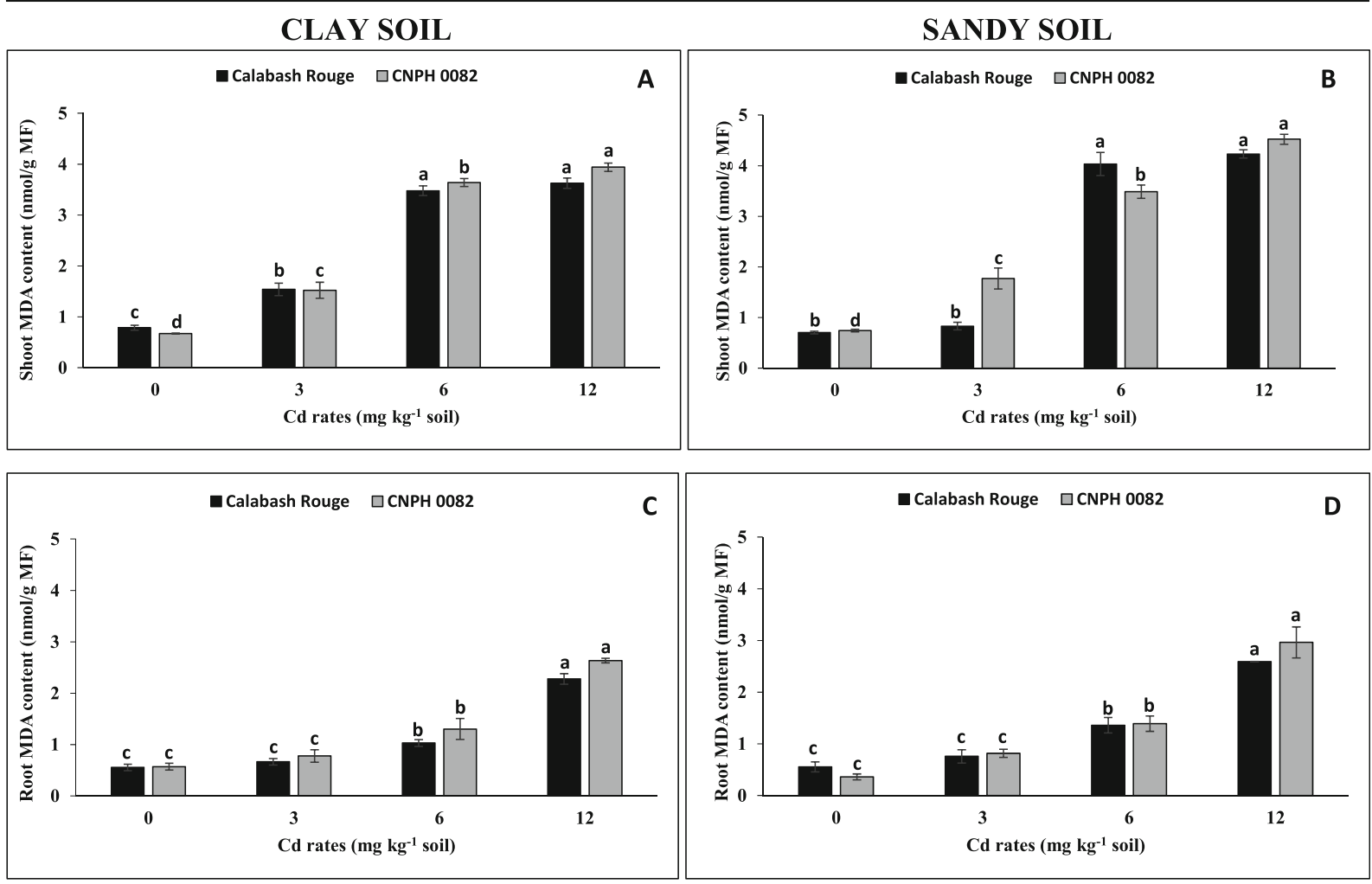

Fig. 8 Lipid peroxidation measured as malondialdehyde (MDA) concentration in shoot $(\mathbf{a}, \mathbf{b})$ and $\operatorname{root}(\mathbf{c}, \mathbf{d})$ of Calabash Rouge and $\mathrm{CNPH} 0082$ genotypes, as related to $\mathrm{Cd}$ rates in two soil types.

Values are the means of three replications \pm SD. Different letters within each soil and each genotype indicate significant differences among means (Tukey, $5 \%$ )

evidence of a reduction in SPAD values in the plants. Cadmium alters the electron transport system and the concentration of those compounds responsible for oligomerization of the chlorophyll protein complex, resulting in the degradation of chlorophyll and consequent chlorosis of the leaves (Gill and Tuteja 2010). Reductions in chlorophyll concentration and consequent disturbed chlorophyll synthesis can be the main cause of decreases in photosynthetic activity in plants when exposed to $\mathrm{Cd}$ (Ekmekçi et al. 2008).

The concentration of Cd in the shoots (Fig. 4a, b) and roots (Fig. 4c, d) of both genotypes increased in response to the availability of the element in the soil, but this linearity between plant capacity absorption and increases on average heavy metal availability is not the rule, and this phenomenon can present numerous variables that cause this non-linearity, such as temperature, aeration, composition and soil moisture, plant competition, and local microbial community. The Calabash Rouge genotype absorbed and transported a greater amount of metal than the CNPH 0082 genotype and such variation may have occurred due to the peculiar

characteristics of each genotype, such as the growth rate, root system, and leaf type, and may also vary according to the element's chemical properties (Nagajyoti et al. 2010).

In both genotypes, greater concentrations of $\mathrm{Cd}$ were observed in the root tissue (Fig. 4c, d) than in the shoots (Fig. 4a, b). The genotypes used in this experiment were found to present mechanisms for metal retention in the root tissue possibly in order to avoid further damage if transported to the shoots. One strategy adopted by plants to minimize the toxic effect of the presence of $\mathrm{Cd}$ is to prevent it reaching the xylem, causing the metal not to accumulate in the shoot and thus not damaging the photosynthetic apparatus of the plant. This can be accomplished by the plant through the synthesis of chelating or physical barriers that prevent the movement of $\mathrm{Cd}$ along the apoplastic pathway (Lux et al. 2011). Plants tolerant to $\mathrm{Cd}$ can protect themselves from its toxic effect by expelling the metal through the roots, chelating and converting $\mathrm{Cd}$ into a non toxic compound, or by depositing it in a non vital cellular compartment, for instance, the vacuole (Lux et al. 2011; Zhu et al. 2011). 


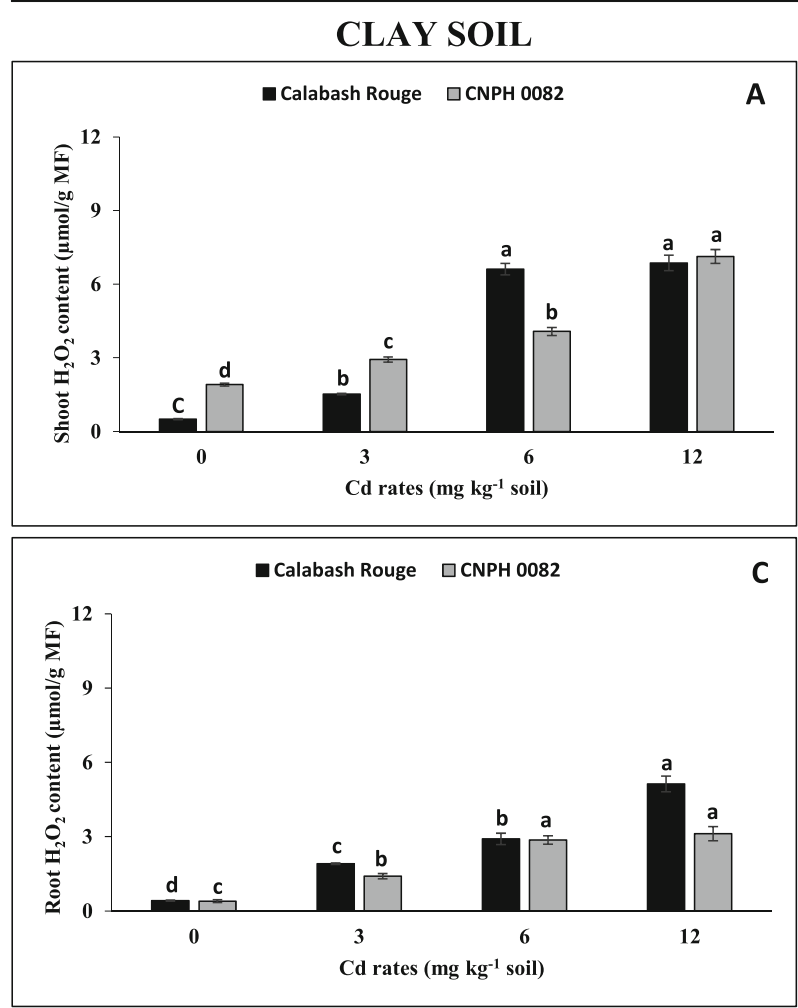

Fig. 9 Hydrogen peroxide $\left(\mathrm{H}_{2} \mathrm{O}_{2}\right)$ concentration in shoot $(\mathbf{a}, \mathbf{b})$ and root $(\mathbf{c}, \mathbf{d})$ of Calabash Rouge and CNPH 0082 genotypes, as related to $\mathrm{Cd}$ rates in two soil types. Values are the means of three
SANDY SOIL
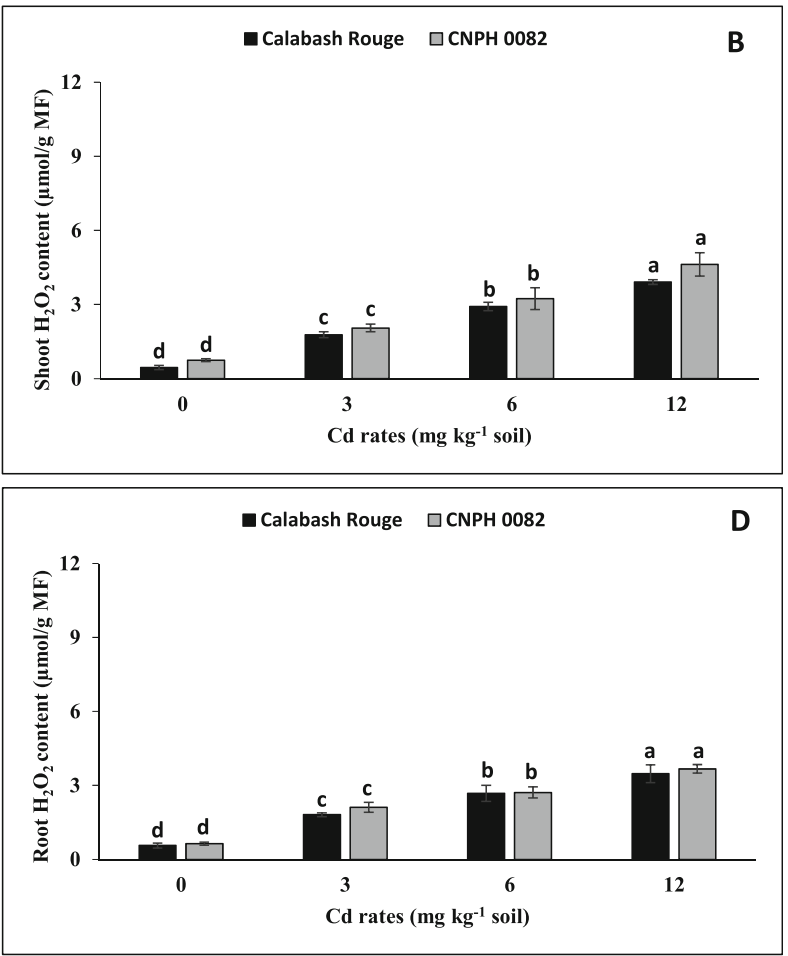

replications \pm SD. Different letters within each soil and each genotype indicate significant differences among means (Tukey, $5 \%$ )

\section{CLAY SOIL}
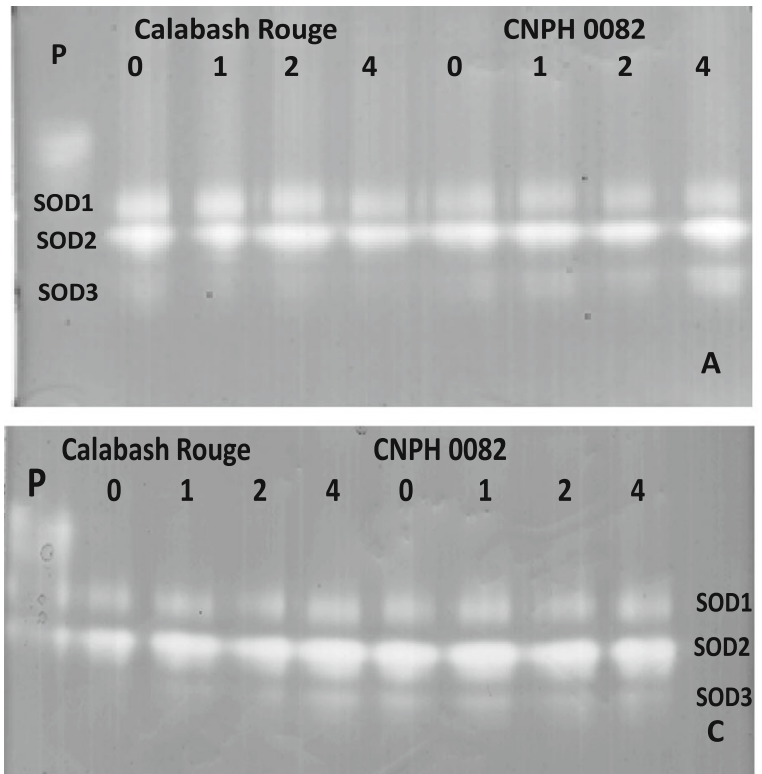

Fig. 10 Activity staining for superoxide dismutase (SOD) following non-denaturing polyacrylamide gel electrophoresis of extracts of shoot $(\mathbf{a}, \mathbf{b})$ and root $(\mathbf{c}, \mathbf{d})$ of Calabash Rouge and CNPH 0082 plants grown

\section{SANDY SOIL}
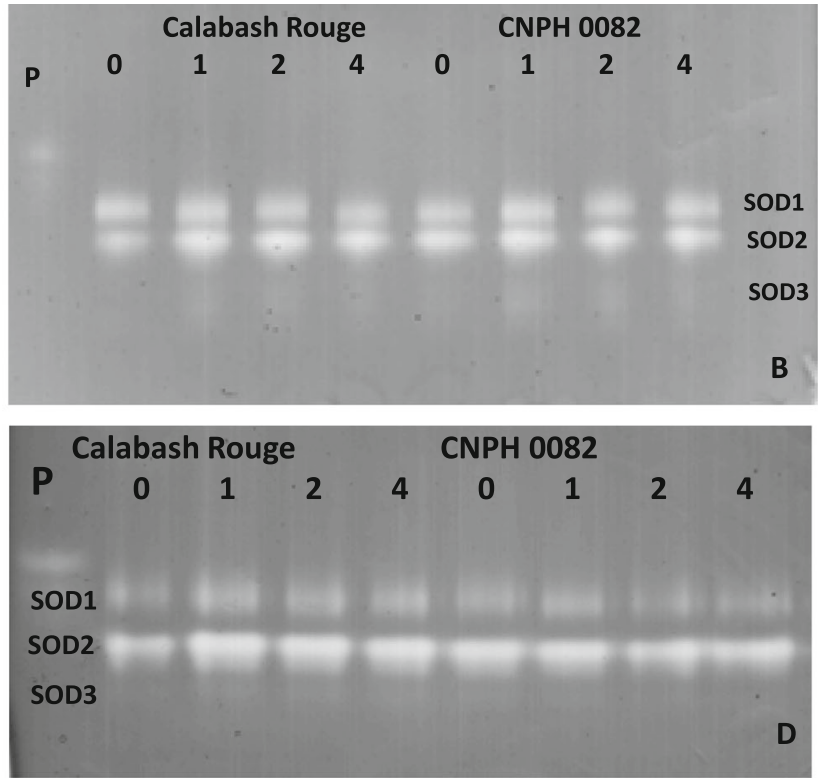

over a 54-day period in the presence of $\mathrm{Cd}$. The lanes listed in soils are as follows: $(P)$ bovine SOD standard; ( $(0)$ control; (1) $\mathrm{Cd}=3 \mathrm{mg} \mathrm{kg}^{-1}$ soil; (2) $\mathrm{Cd}=6 \mathrm{mg} \mathrm{kg}^{-1}$ soil; and (4) $\mathrm{Cd}=12 \mathrm{mg} \mathrm{kg}^{-1}$ soil 


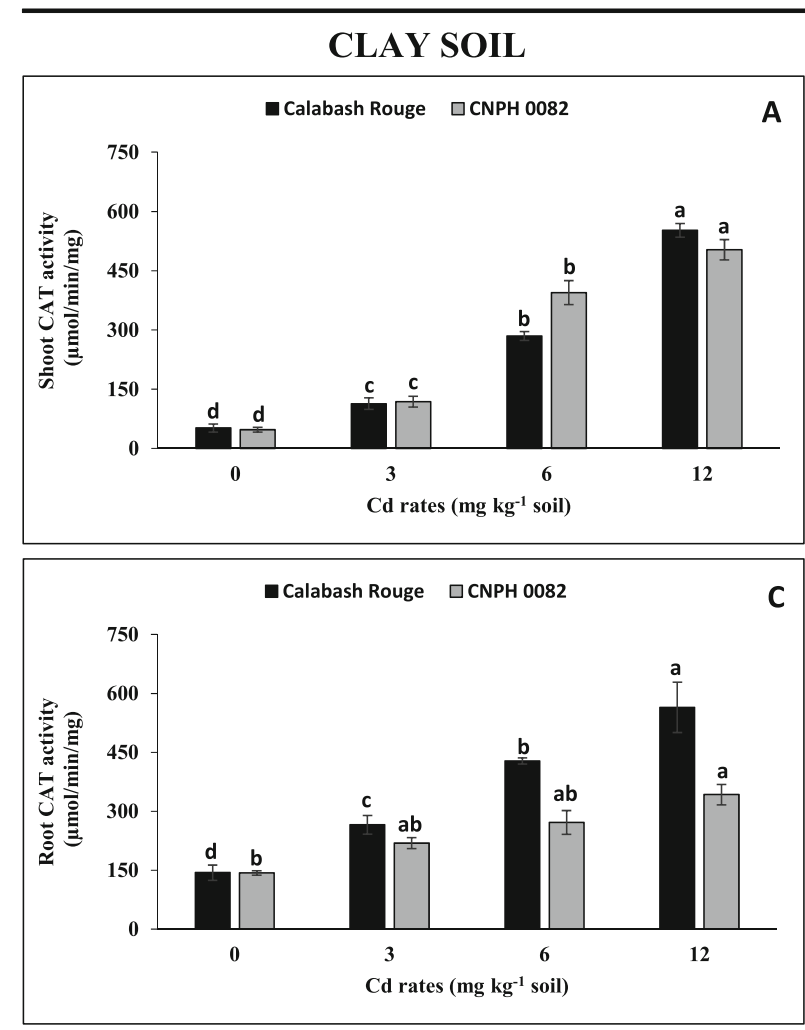

Fig. 11 Catalase activity (CAT) in shoot $(\mathbf{a}, \mathbf{b})$ and root $(\mathbf{c}, \mathbf{d})$ of Calabash Rouge and CNPH 0082 genotypes, as related to Cd rates in two soil types. Values are the means of three replications $\pm \mathrm{SD}$.
SANDY SOIL
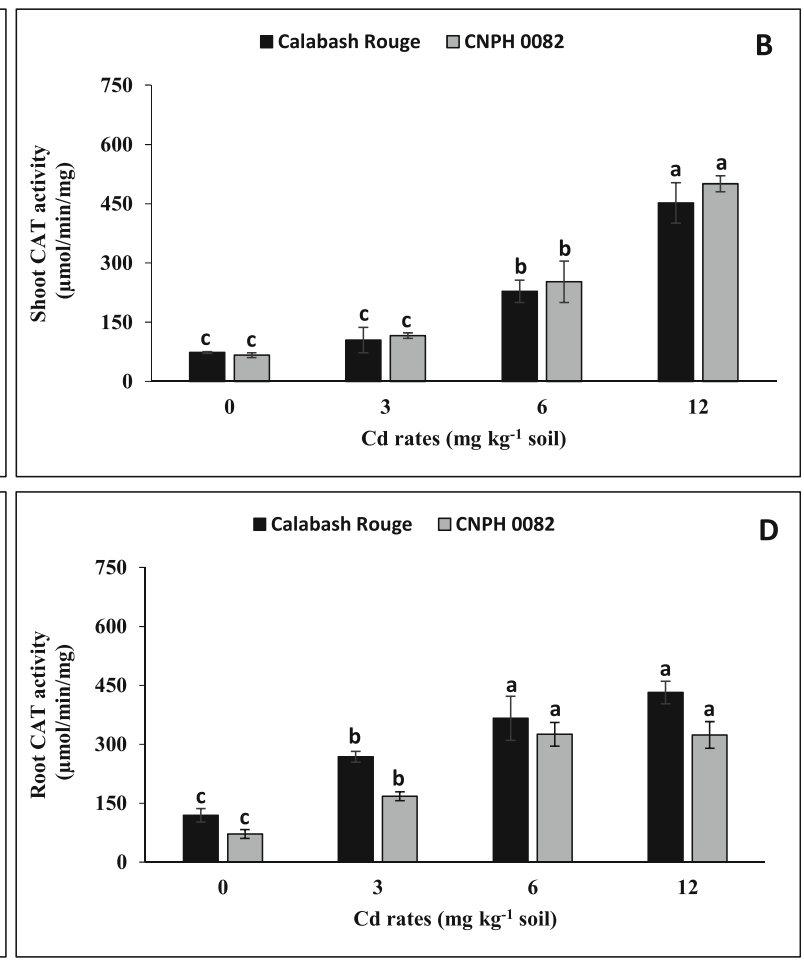

Different letters within each soil and each genotype indicate significant differences among means (Tukey, $5 \%$ )

which may become a risk to human health since this metal is transferred to the beans.

Nitrogen concentration in the shoot tissues of both genotypes was lower under conditions of increased $\mathrm{Cd}$ availability in soils (Fig. 5a, b). When plants absorb high amount of $\mathrm{Cd}$, the metal causes oxidative injuries to the plasma membrane (Gill and Tuteja 2010) and reduces N uptake by the plant (Hatata and Abdel-Aal 2008), thus resulting in lower concentrations of this nutrient in the tissues. This reduction in $\mathrm{N}$ concentration where there is increased availability of metals has been reported in plants grown in environments where there is also high availability of heavy metals, e.g., copper (Quartacci et al. 2001). Hatata and Abdel-Aal (2008) evaluated the effect of $\mathrm{Cd}\left(10,50\right.$, and $\left.100 \mathrm{mmol} \mathrm{L}^{-1}\right)$ in sunflower (Helianthus annuus) and obtained $\mathrm{N}$ concentrations reduced by 60 and $46 \%$ in shoots and root tissues, respectively, when a $\mathrm{Cd}$ concentration of $100 \mathrm{mmol} \mathrm{L}^{-1}$ was compared to control (no $\mathrm{Cd}$ ). There was an increase in $\mathrm{N}$ concentration in the root tissue of plants in response to the $\mathrm{Cd}$ concentrations 
CLAY SOIL
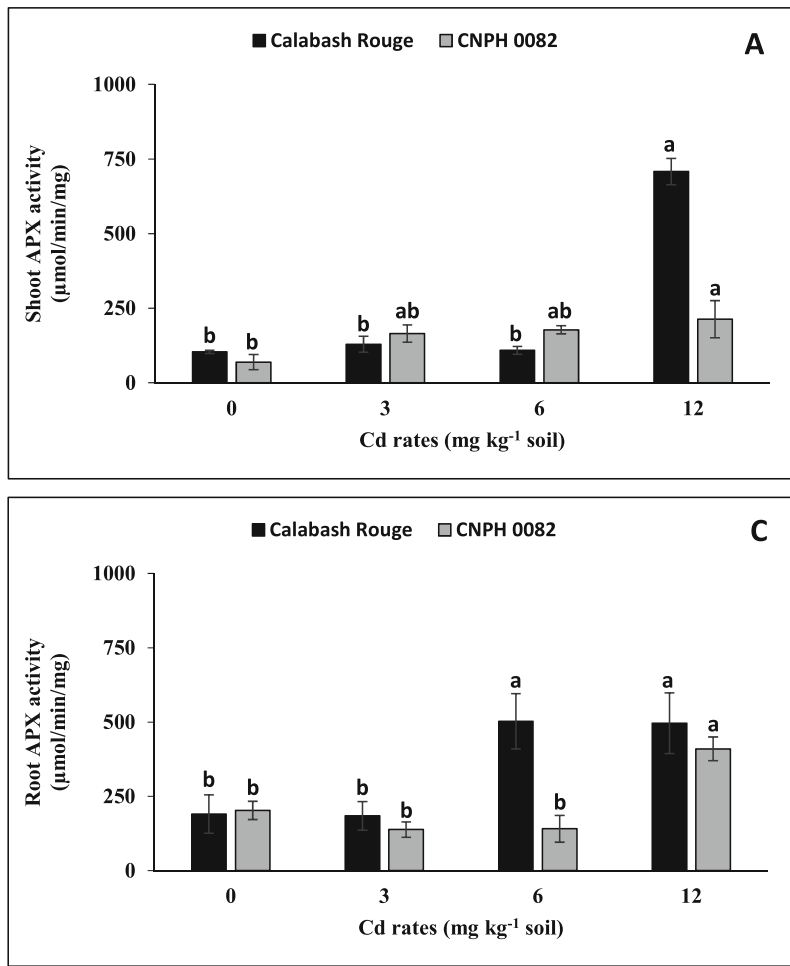

Fig. 12 Ascorbate peroxidase activity (APX) in shoot $(\mathbf{a}, \mathbf{b})$ and root $(\mathbf{c}, \mathbf{d})$ of Calabash Rouge and CNPH 0082 genotypes, as related to $\mathrm{Cd}$ rates in two soil types. Values are the means of three

applied to the soil (Fig. 5c, d). It is known that $\mathrm{NO}_{3}{ }^{-}$is reallocated to the roots when plants are exposed to stress, including stress caused by heavy metals (Hernandez et al. 1997). Recent studies indicate that the reallocation process of $\mathrm{NO}_{3}{ }^{-}$functions as an essential contributor to tolerance to $\mathrm{Cd}$ (Gojon and Gaymard 2010; Li et al. 2010; Chen et al. 2012). This reallocation of $\mathrm{NO}_{3}{ }^{-}$is based on the following observations: (a) the $\mathrm{NO}_{3}{ }^{-}$represents the lowest proportion of all $\mathrm{N}$ reallocated to the roots, and thus the nutritional effect is subtle and insignificant; (b) changes in gene expression and (c) the $\mathrm{Cd}$ distribution between roots and shoots were altered and were positively correlated with the concentrations of $\mathrm{NO}_{3}{ }^{-}$(Chen et al. 2012).

The concentration of metals in soils, the type of soil, and plant species will influence the level of toxicity to the plant since the metal can compete with essential mineral elements, especially cationic micronutrients (Zhang et al. 2002) and, consequently, causing a nutritional imbalance in the plants. Once absorbed by the plant, the $\mathrm{Cd}$ is accumulated in the plant tissue and cellular compartments, which impairs plant metabolism
SANDY SOIL
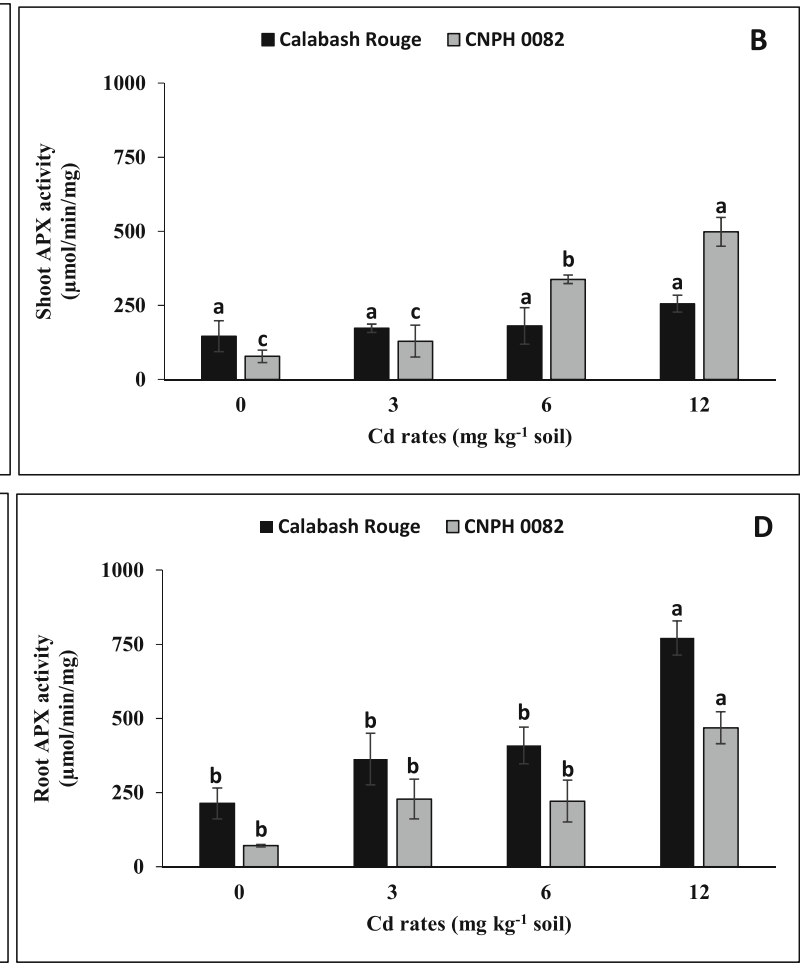

replications \pm SD. Different letters within each soil and each genotype indicate significant differences among means (Tukey, $5 \%$ )

(Hasan et al. 2009). Results available in the literature show that this metal (a) increases the absorption of nutrients in a wide number of plant species, such as in this experiment which resulted in an increase in $\mathrm{P}$ concentration in the shoots of the Calabash Rouge genotype (Fig. 6b) and a reduction in the concentration of this nutrient in root tissues of both cultivars when grown in sandy soil (Fig. 6d), and (b) decreases absorption in other species through competition for the same absorption site, such as in the case of $\mathrm{Mn}$ in the Calabash Rouge genotype grown in sandy soil (Fig. 7b, d). This has been attributed to differences between plant species and the concentration of nutrients available in the growth medium (Safarzadeh et al. 2013). Adverse environmental conditions affect nutrition and metabolism related to $\mathrm{P}$ in plants. The activities of phospholitic enzymes such as acid phosphatase, alkaline phosphatase, and ATPase are altered significantly when plants are exposed to sources of abiotic stress in the environment such as salinity of the culture medium (Ehsanpour and Amini 2003), osmotic stress (Szabo-Nagy et al. 1992), and excess heavy metals (Shah and Dubey 
CLAY SOIL
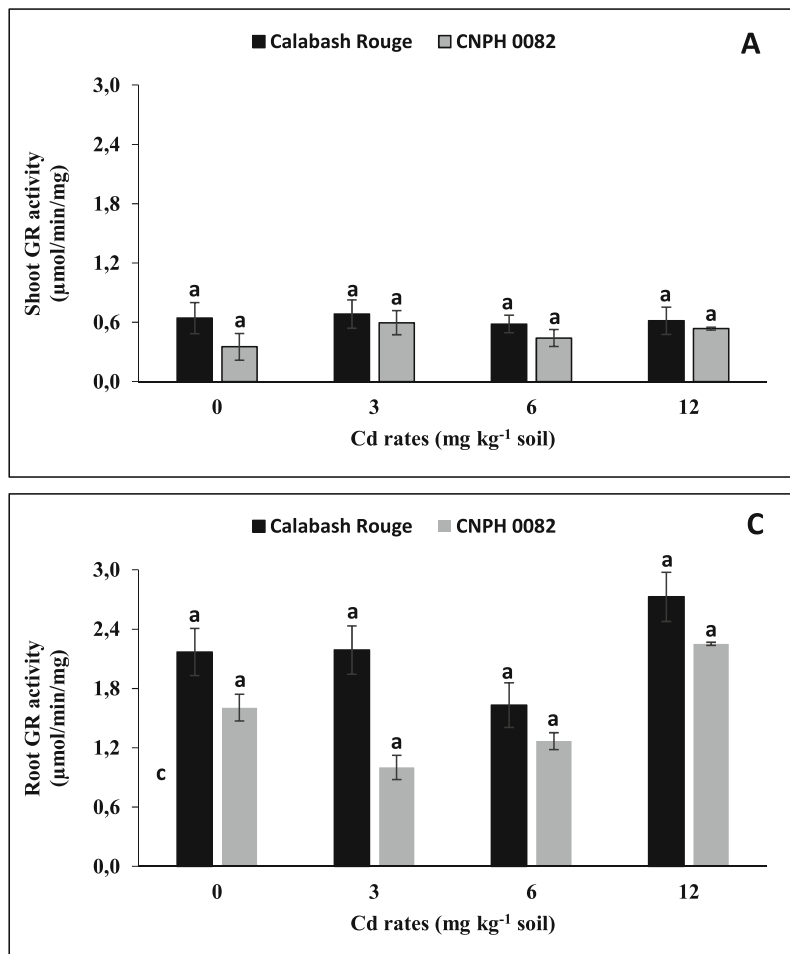

Fig. 13 Glutathione reductase activity (GR) in shoot (a, b) and root $(\mathbf{c}, \mathbf{d})$ of Calabash Rouge and CNPH 0082 genotypes, as related to $\mathrm{Cd}$ rates in two soil types. Values are the means of three

1998). Cadmium can interfere with the absorption, transport, and use of certain nutrients, including $\mathrm{P}$, as shown in pea plants (Metwally et al. 2005) and barley (Guo et al. 2007).

Increasing the amount absorbed and the accumulation of heavy metals in plants can cause osmotic changes, metabolic disturbances, and damage induced by the production of ROS (Gill et al. 2011). Mineral stress induced by $\mathrm{Cd}$ can reduce dry mass production by plants and crop productivity (Marschner 2012). Melo et al. (2011) have also observed inhibition of growth of soybean plants when grown in tropical soils contaminated with $\mathrm{Cd}$.

Cadmium does not directly participate in redox reactions within the cells, but causes oxidative damage due to the production of ROS. In the present study, some key enzymes of the antioxidant system exhibited high levels of activities in roots and shoots of the plants in the presence of Cd. Cadmium treatments applied to the soils caused an increase in MDA content in the tomato shoots and roots (Fig. 8), similar to that found by Melo et al. (2011) in soybean plants. Exposure to high levels of
SANDY SOIL
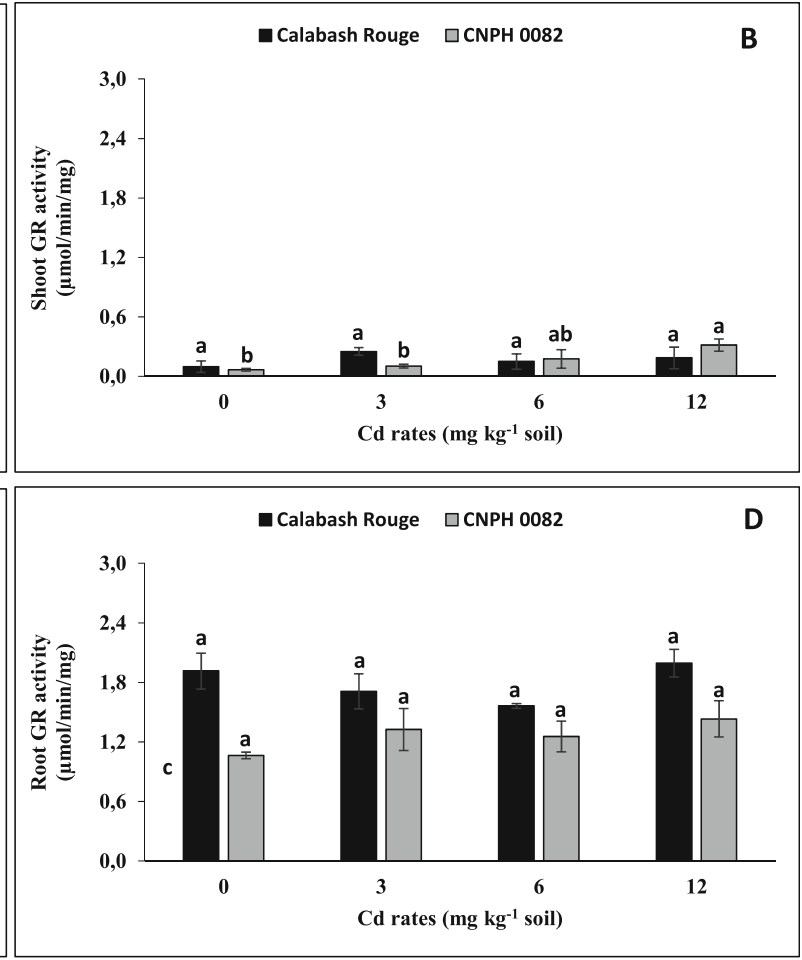

replications $\pm \mathrm{SD}$. Different letters within each soil and each genotype indicate significant differences among means (Tukey, $5 \%$ )

ROS may cause disruption of the homeostasis and cause oxidative damage to macromolecules, which may lead to lipid peroxidation and severe damage to the cell (Gratão et al. 2008). Cadmium caused an increase in MDA content in rice (Hsu and Kao 2007), Bacopa monnieri (Mishra et al. 2006), tomato (Mediouni et al. 2006), Lemma polyrrhiza (John et al. 2007), and Brassica juncea (Mobin and Khan 2007), probably as a result of increased of $\mathrm{H}_{2} \mathrm{O}_{2}$.

Plants produce ROS because of their aerobic metabolism, especially during the respiration process and photosynthesis (Halliwell 2006), but this $\mathrm{H}_{2} \mathrm{O}_{2}$ content remains at a low level due to the activity of the numerous peroxidases such as CAT, APX, and GPOX enzymes (Gill and Tuteja 2010), among others. The production of $\mathrm{H}_{2} \mathrm{O}_{2}$ in both tomato genotypes increased due to exposure to $\mathrm{Cd}$ (Fig. 9), despite increases in activity of the antioxidant complex enzymes.

Three SOD isoenzymes (SOD 1, 2, and 3) were identified following PAGE (Fig. 10) in a similar manner to that reported by Nogueirol et al. (2015) for both CNPH 0082 and Calabash Rouge genotypes and for the $\mathrm{CNPH}$ 

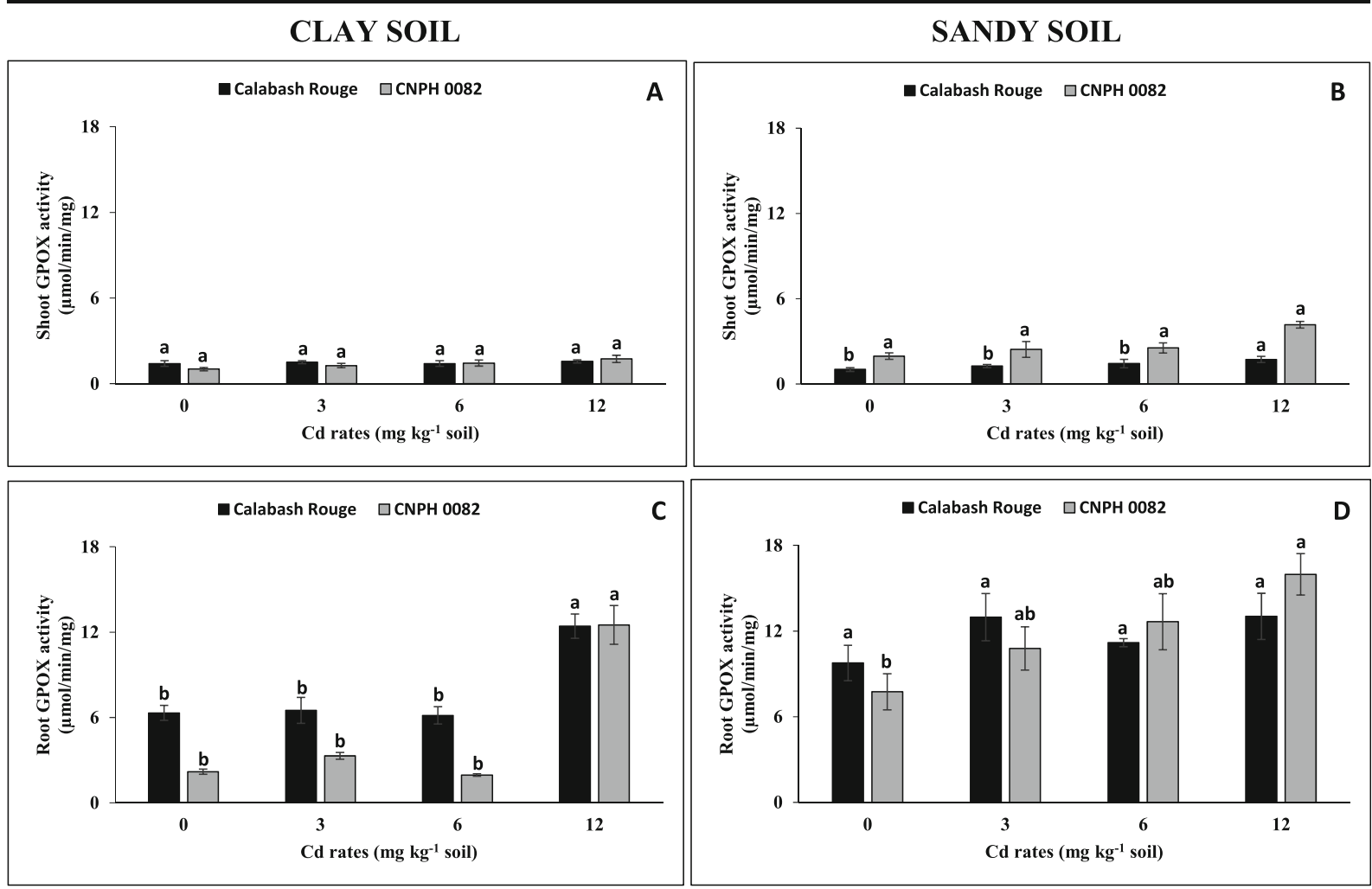

Fig. 14 Guaiacol peroxidase activity (GPOX) in shoot $(\mathbf{a}, \mathbf{b})$ and root (c, d) of Calabash Rouge and CNPH 0082 genotypes, as related to $\mathrm{Cd}$ rates in two soil types. Values are the means of three

0082 genotype only in the presence of Al. When antioxidant enzymes are taken into consideration, the increase in SOD 3 activity observed in the shoots of CNPH 0082 and the roots of Calabash Rouge suggests that this isoenzyme may play an important role in cellular protection against $\mathrm{Cd}$ toxicity. $\mathrm{SOD}$ is involved in the dismutation of $\mathrm{O}^{2-}$ into $\mathrm{H}_{2} \mathrm{O}_{2}$ and is located in different cell organelles (Gratão et al. 2005). The increase in SOD 3 activity observed in the shoots of CNPH 0082 might play an important role in cellular protection against $\mathrm{Al}$ toxicity, whereas in the roots, a continuous increase in SOD activity in plants grown in clay soil can indicate different responses to the soil types used.

The CAT enzyme appears to be important in the defense of the tomato plant against $\mathrm{Cd}$ (Chamseddine et al. 2009), since it has increased activity in the plant tissues where $\mathrm{Cd}$ was accumulated in higher concentration (Fig. 11), exhibiting a different behavior from other studies which have shown that under high quantity of Cd absorbed into the plant, CAT activity was reduced, since this metal causes oxidation of thiol groups in this enzyme (Benavides et al. 2005; Dal Corso et al. 2008). replications \pm SD. Different letters within each soil and each genotype indicate significant differences among means (Tukey, $5 \%$ )

The exposure of tomato plants to Cd resulted in increased APX activity (Fig. 12). Plants, once exposed to the metal, have shown increased activity of this enzyme due to the activation of the ascorbateglutathione cycle (Anjum et al. 2011), since APX acts to reduce $\mathrm{H}_{2} \mathrm{O}_{2}$ by generating one molecule of $\mathrm{H}_{2} \mathrm{O}$ and one molecule of monodehydroascorbate (Benavides et al. 2005). Gill et al. (2012) reported increases in APX activity in Lepidium sativum (plant garden cress) in response to exposure to Cd concentration $(0.22,0.44$, and $0.88 \mathrm{mmol} \mathrm{kg}^{-1}$ of soil).

The GR enzyme, although it is a key enzyme in the ascorbate-glutathione cycle as it protects cells against oxidative damage caused by $\mathrm{Cd}$ and recycles glutathione (Foyer and Noctor 2005), did not exhibit any major changes when the tomato plants were exposed to the metal, except in the shoots of CNPH 0082 grown in sandy soil (Fig. 13). Cadmium can be linked to $\mathrm{SH}$ groups at the active position of the GR enzyme, and through that it can induce the maintenance of glutathione at its reduced state when Cd was supplied at $24 \mu \mathrm{M}$ (Chamseddine et al. 2009). This can explain why $\mathrm{Cd}$ 
changed only the activity of the APX enzyme in the ascorbate-glutathione cycle.

GPOX activity also had high activity in the roots, with similar behavior in both genotypes, indicating this is an important enzyme in the detoxification of cells against $\mathrm{H}_{2} \mathrm{O}_{2}$ (Fig. 14).

\section{Conclusions}

Available Cd contents in clay and sand soil were similar; however, the plants grown in clay soil had higher $\mathrm{N}$, $\mathrm{Mn}$, and $\mathrm{Cd}$ concentrations and showed higher dry mass production. The soil characteristics influence the mineral elements availability for plant uptake.

Cadmium was phytotoxic to tomato plants causing a nutritional imbalance, especially for the metabolisms of $\mathrm{N}, \mathrm{P}$, and Mn. Nitrogen concentration in the plant is lower when exposed to the highest $\mathrm{Cd}$ doses, probably due to a disturbance in the $\mathrm{N}$ metabolism. An alternative to reduce this problem would be the partial supply of this nutrient in the form of $\mathrm{NH}_{4}{ }^{+}$that the plant could readily assimilate, as $\mathrm{Cd}$ may affect nitrate reductase activity and change $\mathrm{N}$ concentration in plant tissue.

An oxidative stress condition was established in response to the Cd treatments applied, which led to changes in peroxidase activity. There is a need for more comprehensive studies involving both the nutritional balance and specific nutrients, such as $\mathrm{N}$, which would investigate the tolerance of plants to stress caused by metals, which would then afford a better understanding of the detoxification mechanisms that could contribute to plant tolerance in areas where there are contaminated metals.

Acknowledgments This work was funded by the Fundação de Amparo à Pesquisa do Estado de São Paulo (FAPESP, Grant number 2009/54676-0). We thank the Conselho Nacional de Desenvolvimento Científico e Tecnológico (CNPq) (F.A.M, B.K.A.S, and R.A.A) and FAPESP (R.C.N) for the fellowship and scholarships granted.

\section{References}

Anjum, N. A., Umar, S., Iqbal, M., \& Khan, N. A. (2011). Cadmium causes oxidative stress in mung bean by affecting the antioxidant enzyme system and ascorbato-glutathione cycle metabolism. Russian Journal of Plant Physiology, 58, 92-99.
Azevedo, R. A., Alas, R. M., Smith, R. J., \& Lea, P. J. (1998). Response of antioxidant enzymes to transfer from elevated carbon dioxide to air and ozone fumigation, in the leaves and roots of wild-type and a catalase-deficient mutant of barley. Physiologia Plantarum, 104, 280-292.

Azevedo, R. A., Gratão, P. L., Monteiro, C. C., \& Carvalho, R. F. (2012). What is new in the research on cadmium-induced stress in plants? Food and Energy Security, 1, 133-140.

Ben Ammar, W., Mediouni, C., Tray, B., Ghorbel, M. H., \& Jemal, F. (2008). Glutathione and phytochelatin contents in tomato plants exposed to cadmium. Biologia Plantarum, 52, 314 320.

Benavides, M. P., Gallego, S. M., \& Tomaro, M. L. (2005). Cadmium toxicity in plants. Brazilian Journal of Plant Physiology, 17, 21-34.

Benzarti, S., Hamdi, H., \& Mohri, S. (2010). Response of antioxidative enzymes and apoplastic bypass transport in Thlaspicae rulescens and Raphanus sativus to cadmium stress. International Journal of Phytoremediation, 12, 733744.

Bradford, M. M. (1976). A rapid and sensitive method for quantitation of microgram quantities of protein utilizing the principle of protein dye-binding. Analytical Biochemistry, 72, 248-254.

Cakmak, I., \& Horst, W. J. (1991). Effect of aluminium on lipid peroxidation, superoxide dismutase catalase and peroxidase activities in root tips of soybean (Glycine max). Physiologia Plantarum, 83, 463-468.

Carvalho, R. F., Monteiro, C. C., Caetano, A. C., Dourado, M. N., Gratão, P. L., Haddad, C. K. B., Peres, L. E. P., \& Azevedo, R. A. (2013). Leaf senescense in tomato mutants as affected by irradiance and phytohormones. Biologia Plantarum, 57, 749-757.

Chamseddine, M., Wided, B. A., Guy, H., \& Marie-Edith, C. (2009). Cadmium and copper induction of oxidative stress and antioxidative response in tomato (Solanum lycopersicon) leaves. Plant Growth Regulation, 57, 89-99.

Chen, Z., Zhang, H., Guo, W., Zhang, L., Tian, Y., \& Wei, X. (2012). Cadmium stress on wheat morphology: germination and growth. Advances in Materials Research, 356-360, 1075-1078.

Chou, T., Chao, Y., Huang, W., Hong, C., \& Kao, C. H. (2011). Effect of magnesium deficiency on antioxidant status and cadmium toxicity. Journal of Plant Physiology, 168, 10211030.

Clemens, S. (2006). Toxic metal accumulation, responses to exposure and mechanisms of tolerance in plants. Biochimie, 88 , $1707-1719$.

Conama-Environmental National Council-Resolution no 420 of December 28 (2009). Provides criteria and guiding values of soil quality regarding presence of chemicals and establishes guidelines for environmental management of areas contaminated by these substances resulting from human activities. Accessed on 20 Apr 2015.

Dal Corso, G., Farinati, S., Maistri, S., \& Furini, A. (2008). How plants cope with cadmium: staking all on metabolism and gene expression. Journal of Integrative Plant Biology, 50, 1268-1280.

Delperee, C., \& Lutts, S. (2008). Growth inhibition occurs independently of cell mortality in tomato (Solanum lycopersicum) 
exposed to high cadmium concentrations. Journal of Integrative Plant Biology, 50, 300-310.

Djebali, W., Hédiji, H., Abbes, Z., Barhoumi, Z., Yaakoubi, H., Zoghlami, L. B., \& Chábi, W. (2010). Aspects on growth and anatomy of internodes and leaves of cadmium-treated Solanum lycopersicum L. plants. Journal of Biological Research, 13, 75-84.

Dourado, M. N., Martins, P. F., Quecine, M. C., Piotto, F. A., Souza, L. A., Franco, M. R., Tezotto, T., \& Azevedo, R. A. (2013). Burkholderia sp. SCMS54 reduces cadmium toxicity and promotes growth in tomato. Annals of Applied Biology, 163, 494-507.

Dourado, M. N., Souza, L. A., Martins, P. F., Peters, L. P., Piotto, F. A., \& Azevedo, R. A. (2014). Burkholderia sp. SCMS54 triggers a global stress defense in tomato enhancing cadmium tolerance. Water, Air, and Soil Pollution, 225, 1-16.

Dourado, M. N., Franco, M. R., Peters, L. P., Martins, P. F., Souza, L. A., Piotto, F. A., \& Azevedo, R. A. (2015). Antioxidant enzymes activities of Burholderia spp. strains-oxidative responses to Ni toxicity. Environmental Science and Pollution Research International, 22, 19922-19932.

Ehsanpour, A. A., \& Amini, F. (2003). Effect of salt and drought stress on acid phosphatase activities in alfalfa (Medicago sativa L.) explants under in vitro culture. African Journal of Biotechnology, 2, 133-135.

Ekmekçi, Y., Tanyolaç, D., \& Ayhan, B. (2008). Effects of cadmium on antioxidant enzyme and photosynthetic activities in leaves of two maize cultivars. Journal of Plant Physiology, $165,600-611$.

Environmental Protection Agency, USA, Method 3052: Microwave assisted acid digestion of siliceous and organically based matrices (1996). Environmental Protection Agency, Washington.

Feng, J., Shi, Q., Wang, X., Wei, M., Yang, F., \& Xu, H. (2010). Silicon supplementation ameliorated the inhibition of photosynthesis and nitrate metabolism by cadmium $(\mathrm{Cd})$ toxicity in Cucumis sativus L. Scientia Horticulturae, 123, 521-530.

Fojtová, M., \& Kovarík, A. (2000). Genotoxic effect of cadmium is associated with apoptotic changes in tobacco cells. Plant, Cell and Environment, 23, 531-537.

Foyer, C. H., \& Noctor, G. (2005). Oxidant and antioxidant signalling in plants: a re-evaluation of the concept of oxidative stress in a physiological context. Plant, Cell and Environment, 28, 1056-1071.

Gallego, S. M., Pena, L. B., Barcia, R. A., Azpilicueta, C. E., Iannone, M. F., Rosales, E. P., Zawoznik, M. S., Groppa, M. D., \& Benavides, M. P. (2012). Unravelling cadmium toxicity and tolerance in plants: insight into regulatory mechanisms. Environmental and Experimental Botany, 83, 33-46.

Gay, C., Collins, J., \& Gebicki, J. M. (1999). Hydroperoxide assay with the ferric-xylenol orange complex. Analytical Biochemistry, 273, 149-155.

Gill, S. S., \& Tuteja, N. (2010). Reactive oxygen species and antioxidant machinery in abiotic stress tolerance in crop plants. Plant Physiology and Biochemistry, 48, 909-930.

Gill, S. S., Khan, N. A., \& Tuteja, N. (2011). Differential cadmium stress tolerance in five Indian mustard (Brassica juncea L.) cultivars, an evaluation of the role of antioxidant machinery. Plant Signaling \& Behavior, 6, 293-300.

Gill, S. S., Khan, N. A., \& Tuteja, N. (2012). Cadmium at high dose perturbs growth, photosynthesis and nitrogen metabolism while at low dose it up regulates sulfur assimilation and antioxidant machinery in garden cress (Lepidium sativum L.). Plant Science, 182, 112-120.

Gojon, A., \& Gaymard, F. (2010). Keeping nitrate in the roots: an unexpected requirement for cadmium tolerance in plants. Journal of Molecular Cell Biology, 2, 299-301.

Gratão, P. L., Prasad, M. N. V., Cardoso, P. F., Lea, P. J., \& Azevedo, R. A. (2005). Phytoremediation: green technology for the clean up of toxic metals in the environment. Brazilian Journal of Plant Physiology, 17, 53-64.

Gratão, P. L., Monteiro, C. C., Antunes, A. M., Peres, L. E. P., \& Azevedo, R. A. (2008). Acquired tolerance of tomato (Lycopersicon esculentum cv. Micro-Tom) plants to cadmium-induced stress. Annals of Applied Biology, 153, 321-333.

Gratão, P. L., Monteiro, C. C., Carvalho, R. F., Tezotto, T., Piotto, F. A., Peres, L. E., \& Azevedo, R. A. (2012). Biochemical dissection of diageotropica and Never ripe tomato mutants to Cd-stressful conditions. Plant Physiology and Biochemistry, 56, 79-96.

Gratão, P. L., Monteiro, C. C., Carvalho, R. F., Tezotto, T., Carvalho, R. F., Alves, L. R., Peters, L. P., \& Azevedo, R. A. (2015). Cadmium stress antioxidant responses and rootto-shoot communication in grafted tomato plants. Biometals, $28,803-816$.

Guo, T. R., Zhang, G. P., Zhou, M. X., Wu, F. B., \& Chen, J. X. (2007). Influence of aluminum and cadmium stresses on mineral nutrition and root exudates in two barley cultivars. Pedosphere, 17, 505-512.

Halliwell, B. (2006). Redox biology is fundamental theme of aerobic life. Plant Physiology, 141, 312-322.

Hasan, S. A., Fariduddin, Q., Ali, B., Hayat, S., \& Ahmad, A. (2009). Cadmium: toxicity and tolerance in plants. Journal of Environmental Biology, 30, 165-174.

Hatata, M. M., \& Abdel-AAL, E. A. (2008). Oxidative stress and antioxidant defense mechanisms in response to cadmium treatments. American-Eurasian Journal of Agricultural \& Environmental Sciences, 4, 655-669.

Hernandez, L. E., Gárate, A., \& Carpena-Ruiz, R. (1997). Effects of cadmium on the uptake, distribution and assimilation of nitrate in Pisum sativum. Plant and Soil, 189, 97-106.

Hoagland, D., \& Arnon, D. I. (1950). The water-culture method for growing plants without soil (Vol. 347, pp. 1-32). Berkeley: California Agricultural Experiment Station.

Hsu, Y. T., \& Kao, C. H. (2007). Toxicity in leaves of rice exposed to cadmium is due to hydrogen peroxide accumulation. Plant and Soil, 298, 231-241.

Iannone, M. F., Groppa, M. D., \& Benavides, M. P. (2015). Cadmium induces different biochemical responses in wild type and catalase-deficient-tobacco plants. Environmental and Experimental Botany, 109, 201-211.

International Cadmium Association (ICdA). (2012). Level of cadmium in the environment. http://cadmium.ionainteractive. com/pg n.php?id menu $=6$.

John, R., Ahmad, P., Gadgil, K., \& Sharma, S. (2007). Antioxidative response of Lemna polyrrhiza L. to cadmium stress. Journal of Environmental Biology, 28, 583-589.

Li, J. Y., Fu, Y. L., Pike, S. M., Bao, J., Tian, W., Zhang, Y., Chen, C. Z., Zhang, Y., Li, H. M., Huang, J., Li, L. G., Schroeder, J. I., Gassmann, W., \& Gong, J. M. (2010). The Arabidopsis nitrate transporter NRT1.8 functions in nitrate removal from 
the xylem sap and mediates cadmium tolerance. Plant Cell, 22, 1633-1646.

Liu, S. L., Yang, R. J., Ma, M. D., Dan, F., Zhao, Y., Jiang, P., \& Wang, M. H. (2015). Effects of exogenous NO on the growth, mineral nutrient content, antioxidant system, and ATPase activities of Trifolium repens L. plants under cadmium stress. Acta Physiologiae Plantarum, 37, 1721.

Lux, A., Martinka, M., Vaculík, M., \& White, P. J. (2011). Root responses to cadmium in rhizosphere: a review. Journal of Experimental Botany, 62, 21-37.

Malavolta, E., Vitti, G. C., \& Oliveira, A. S. (1997). Avaliação do estado nutricional de plantas: Princípios e aplicações (2nd ed.). Piracicaba: Associação Brasileira para Pesquisa de Potassa e do Fosfato. 319p.

Marschner, P. (2012). Marschner's mineral nutrition of higher plants (3rd ed.). London: Academic Press.

Matsuno, H., \& Uritani, I. (1972). Physiological behavior of peroxidases isoenzymes in sweet potato root tissue injured by cutting or with black rot. Plant and Cell Physiology, 13, 1091-1101.

Mediouni, C., Benzarti, O., Tray, B., Ghorbel, M. H., \& Jemal, F. (2006). Cadmium and copper toxicity for tomato seedlings. Agronomy for Sustainable Development, 26, 227-232.

Mehlich, A. (1984). Mehlich-3 soil test extractant: a modification of Mehlich-2 extractant. Communications in Soil Science and Plant Analysis, 15, 1409-1416.

Melo, L. C. A., Alleoni, L. R. F., Carvalho, G., \& Azevedo, R. A. (2011). Cadmium- and barium-toxicity effects on growth and antioxidant capacity of soybean (Glycine max. L.) plants, grown in two soil types with different physicochemical properties. Journal of Plant Nutrition and Soil Science, 1-13.

Metwally, A., Safronova, V. I., Belimov, A. A., \& Dietz, K. J. (2005). Genotypic variation of the response to cadmium toxicity in Pisum sativum L. Journal of Experimental Botany, 409, 167-178.

Mihara, M., Uchiyama, M., \& Fukuzawa, K. (1980). Thiobarbituric acid value on fresh homogenate of rat as a parameter of lipid peroxidation in aging, $\mathrm{CCl}_{4}$ intoxication, and vitamin E deficiency. Biochemical Medicine, 23, 302311.

Mishra, S., Srivastava, S., Tripathi, R. D., Govindarajan, R., Kuriakose, S. V., \& Prasad, M. N. V. (2006). Phytochelatin synthesis and response of antioxidants during cadmium stress in Bacopa monnieri L. Plant Physiology and Biochemistry, 44, 25-37.

Mobin, M., \& Khan, N. A. (2007). Photosynthetic activity, pigment composition and antioxidative response of two mustard (Brassica juncea) cultivars differing in photosynthetic capacity subjected to cadmium stress. Journal of Plant Physiology, 164, 601-610.

Monteiro, C. C., Carvalho, R. F., Gratão, P. L., Carvalho, G., Tezotto, T., Medici, L. O., Peres, L. E. P., \& Azevedo, R. A. (2011). Biochemical responses of the ethylene in sensitive Never ripe tomato mutant subjected to cadmium and sodium stresses. Environmental and Experimental Botany, 71, 306320.

Nagajyoti, P. C., Lee, K. D., \& Sreekanth, T. V. M. (2010). Heavy metals, occurrence and toxicity for plants: a review. Environmental Chemistry Letters, 8, 199-216.

Nogueirol, R. C., Monteiro, F. A., Gratão, P. L., Borgo, L., \& Azevedo, R. A. (2015). Tropical soils with high aluminum concentrations cause oxidative stress in two tomato genotypes. Environmental Monitoring and Assessment, 187, 7388.

Peijnenburg, W., Baerselman, R., de Groot, A., Jager, T., Leenders, D., Posthuma, L., \& Van Veen, R. (2000). Quantification of metal bioavailability for lettuce (Lactuca sativa L.) in field soils. Archives of Environmental Contamination and Toxicology, 39, 420-430.

Piotto, F. A. (2012). Avaliação de tolerância ao cádmio em tomateiro (Solanum lycopersicum L.). Resource document. Escola Superior de Agricultura Luiz de Queiroz, Universidade de São Paulo, Ph.D. Thesis (in Portuguese).

Pizzaia, D. (2013). Genotoxicidade do cádmio em tomateiro (Solanum lycopersicum L.). Resource document. Escola Superior de Agricultura Luiz de Queiroz, Universidade de São Paulo, Ph.D. Thesis (in Portuguese).

Quartacci, M. F., Cosi, E., \& Navari-Izzo, F. (2001). Lipids and NADPH-dependent superoxide production in plasma membranes vesicles from roots of wheat grown under copper deficiency or excess. Journal of Experimental Botany, 52, 77-84.

Rendón, M. Y., Gratão, P. L., Salva, T. J. G., Azevedo, R. A., \& Bragagnolo, N. (2013). Antioxidant enzyme activity and hydrogen peroxide content during the drying of Arabica coffee beans. European Food Research and Technology, 236, 753-758.

Rodecap, K. D., David, T. T., \& Lee, E. H. (1994). Iron nutrition influence on cadmium accumulation by Arabidopsis thaliana (L.) Heynh. Journal of Environmental Quality, 23, 239-246.

Safarzadeh, S., Ronaghi, A., \& Karimian, N. (2013). Effect of cadmium toxicity on micronutrient concentration, uptake and partitioning in seven rice cultivars. Archives of Agronomy and Soil Science, 59, 231-245.

Sanità Di Toppi, L., \& Gabrielli, R. (1999). Response to cadmium in higher plants. Environmental and Experimental Botany, 41, 105-130.

SAS Institute. (2002). SAS: user's guide: statistics (6th ed.). Cary: SAS Institute.

Shah, K., \& Dubey, R. S. (1998). Cadmium suppresses phosphate level and inhibits the activity of phosphatases in growing rice seedlings. Journal of Agronomy and Crop Science, 180, 223231.

Shentu, J., He, Z., Yang, X. E., \& Li, T. (2008). Accumulation properties of cadmium in a selected vegetable-rotation system of Southeastern China. Journal of Agricultural and Food Chemistry, 56, 6382-6388.

Souza, L. A., Piotto, F. A., Nogueirol, R. C., \& Azevedo, R. A. (2013). Use of non-hyperaccumulator plant species for the phytoextraction of heavy metals using chelating agents. Science in Agriculture, 70, 290-295.

Su, Y., Liu, J., Lu, Z., Wang, X., Zhang, Z., \& Shi, G. (2014). Effects of iron deficiency on subcellular distribution and chemical forms of cadmium in peanut roots in relation to its translocation. Environmental and Experimental Botany, 97, 40-48.

Swartjes, F. A., Dirven-Van Breemen, E. M., Otte, P. F., van Beelen, P., Rikken, M. G. J., Tuinstra, J., Spijker, J., \& Lijzen, J. P. A. (2007). Human health risks due to consumption of vegetables from contaminated sites. RIVM. 
Szabo-Nagy, A., Galiba, G., \& Erdei, L. (1992). Induction of soluble phosphatases under ionic and non-ionic osmotic stresses in wheat. Journal of Plant Physiology, 140, 629-633.

Verbruggen, N., Hermans, C., \& Schat, H. (2009). Mechanisms to cope with arsenic or cadmium excess in plants. Current Opinion in Plant Biology, 12, 364-372.

Zhang, G. P., Fukami, M., \& Sekimoto, H. (2002). Influence of cadmium on mineral concentrations and yield components in wheat genotypes differing in Cd tolerance at seedling stage. Field Crops Research, 77, 93-98.

Zhu, X. F., Zheng, C., Hu, Y. T., Jiang, T., Liu, Y., Dong, N. Y., Yang, J. L., \& Zheng, S. J. (2011). Cadmium-induced oxalate secretion from root apex is associated with cadmium exclusion and resistance in Lycopersicon esculentum. Plant, Cell and Environment, 34, 1055-1064. 